\title{
RADIOCARBON CHRONOLOGY OF CENTRAL ALASKA: TECHNOLOGICAL CONTINUITY AND ECONOMIC CHANGE
}

\author{
Ben A Potter \\ Department of Anthropology, University of Alaska Fairbanks, 310 Eielson Building, Fairbanks, Alaska 99775, USA. \\ Email: ffbap3@uaf.edu.
}

\begin{abstract}
This research presents the first comprehensive radiocarbon chronology for central Alaska, encompassing the late Pleistocene and Holocene archaeological record. Dated component distributions, comprised of $274{ }^{14} \mathrm{C}$ dates from 160 components, indicate changing land-use strategies and subsistence economies, reflecting primarily lowland exploitation of bison, wapiti, and birds prior to $6000 \mathrm{cal} \mathrm{BP}$, followed by increasing caribou and fish exploitation and use of upland areas. Microblade technology is conserved from the earliest components to $\sim 1000 \mathrm{cal} \mathrm{BP}$, and this continuity is not reflected in current cultural history sequences. Using component abundance as a proxy for population, initial colonization is associated with climate amelioration after $\sim 14,000 \mathrm{cal} \mathrm{BP}$, and population declines are associated with the Younger Dryas $(13,000-12,000 \mathrm{cal}$ BP) and initial establishment of widespread spruce forests (10,000-9000 cal BP).
\end{abstract}

\section{INTRODUCTION}

The archaeology of central Alaska, defined here as the Tanana, Susitna, and Copper River basins, encompasses an important record (Figure 1). This region is arguably the longest continuously inhabited area in the Western Hemisphere (Holmes et al. 1996; this paper). Archaeological data has the potential to contribute significantly to ongoing debates about the colonization of the New World and late Pleistocene extinctions (Hofman and Todd 2001; Grayson and Meltzer 2002; Waguespack and Surovell 2003; Shapiro et al. 2004). Ethnoarchaeological work on subsistence, settlement, and landuse strategies of hunter-gatherers in high-latitude environments have proven important in broader anthropological theory building (Amsden 1977; Binford 1977, 1978, 1980, 1991; Enloe 1993). However, synthetic work to date has typically been restricted to a few well-known sites (Sheppard et al. 1991), restricted to a limited time frame (Hamilton and Goebel 1999; Mason et al. 2001; Bever 2006) or a limited geographic area (Dixon et al. 1985).

Most current interpretations of prehistory are derived from cultural historical frameworks, which are more descriptive than explanative. These cultural sequences are based primarily on presence/ absence of specific lithic tool types and technologies, rather than on differences in subsistence and land-use strategies, site structure, and organization (e.g. Cook and McKennan 1970; Cook 1975; Bacon 1977; Dixon 1985; Powers and Hoffecker 1989; West 1996b). There are limitations to these conceptual approaches as applied to assemblages in this region. These archaeological constructs are descriptive and employ normative concepts of culture, offering relatively few avenues for testing hypotheses for cultural change or adaptation, and can mask patterning in assemblage variability (Binford 1983). Cultural historical interpretations typically rely on relatively few excavated sites, increasing the potential effects of palimpsests on identifying discrete depositional or activity sets (Schiffer 1976; Carr 1985). Dry Creek Component 2 (C2) is a clear example: it is used as an exemplar of the microblade-bearing Denali complex (Powers et al. 1983; Dixon 1985; Hamilton and Goebel 1999), yet only 36\% of the spatial clusters contain microblade technology (Potter 2005; Bever 2006). Many of the culturally "diagnostic" artifact types/classes are not restricted in time. The data presented here demonstrates long-term technological continuity that requires a re-evaluation of current cultural constructs and alternate approaches to explaining interassemblage variability.

In the last $30 \mathrm{yr}$, numerous cultural resource management and academic investigations have resulted in a great increase in empirical data, particularly radiocarbon-dated components, which have yet to be fully evaluated. Most of these data have never been synthesized on a regional basis, nor used as proxies to evaluate population trends. These dated components represent a useful data set for 


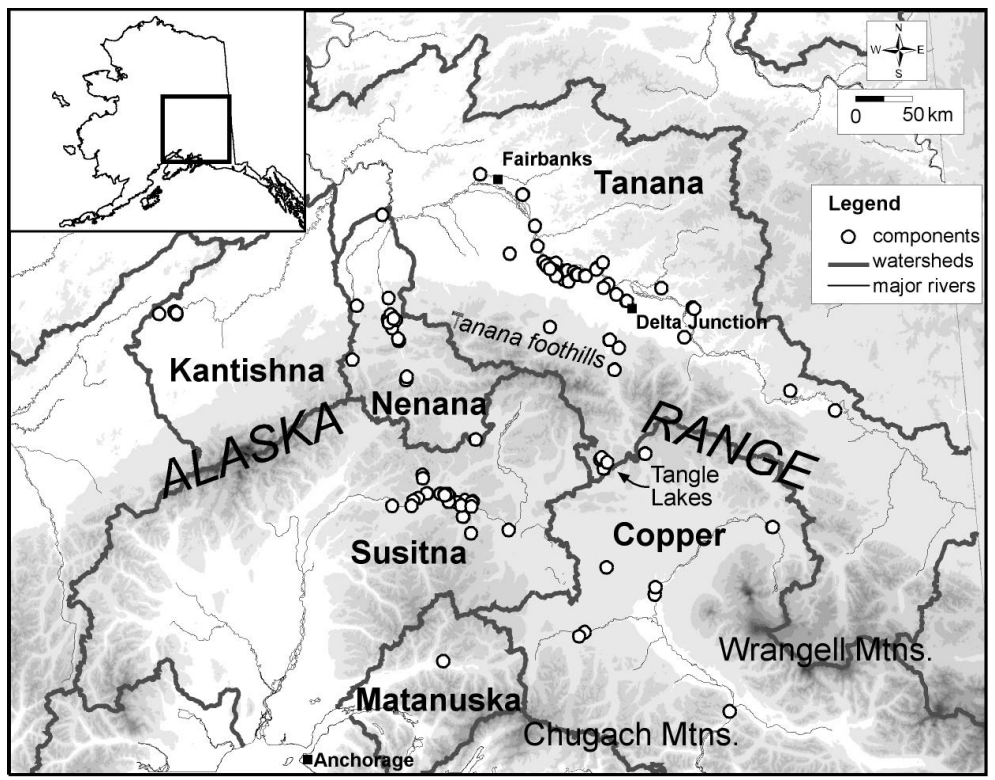

Figure 1 Central Alaska study area, showing dated component locations (elevation shaded in 500-m asl increments). The 2006-2007 surveys described in the text occurred between Fairbanks and Delta Junction south of the Tanana River.

estimating baseline data on technology and economy, as a first step for analyzing interassemblage variability.

This article addresses the limitations in previous intersite analyses by synthesizing a comprehensive record of ${ }^{14} \mathrm{C}$-dated components and identifying major patterns of technological and economic change. Ambiguities and avenues for further inquiry are evaluated, and implications for cultural history are described. Detailed analysis patterning among lithic technology, faunal remains, residential and logistical mobility, and land use in the Holocene are presented in Potter (2008). The cultural transformation at $\sim 1000 \mathrm{cal} \mathrm{BP}$ is explored through competing models of cultural change, population replacement, and taphonomic bias in Potter (forthcoming).

\section{Technology and Chronology in Central Alaska}

Cultural constructs in this region have been typically created on the basis of co-occurring sets of features at the level of attribute, type, and class. Thus, presence or absence of a particular type of projectile point (e.g. Chindadn, Kavik, side-notched) or class of lithics (e.g. flake burin), or even technology (e.g. microcore and blade) has been used to demarcate cultural entities, in the form of traditions, phases, or complexes, based on the proclivities of the originator. Cultural sequences vary somewhat, but most follow a basic pattern: an early period (>13,000 cal BP) marked by considerable technological variability (e.g. Chindadn complex, Nenana complex, East Beringian tradition, Northern Paleoindian tradition); followed by an early Holocene period dominated by microblade technology (e.g. Denali complex); followed by a mid-Holocene period associated with new technology (notched bifaces, notched cobbles, tabular cores) and possible continuation of microblade technology (e.g. Northern Archaic tradition, Tuktu phase, Denali phase); followed by the late Holocene Athabascan tradition, associated with increased organic technology and presence of housepits and cache pits (e.g. Cook and McKennan 1970; Dixon 1985; Holmes 2001). 
Ambiguities have been identified that affect these basic constructs and sequences, such as potential late occurrence of microblade and wedge-core technology (Cook 1969; Shinkwin 1979; Dixon 1985; Bowers 1999) and potential co-occurrence with notched bifaces, hallmarks of the Northern Archaic tradition (Bacon 1977; Cook and Gillispie 1986; Holmes 1986; Clark 2001; Ackerman 2004). The transition from early to middle Holocene complexes is also not well understood, and an occupation hiatus has been posited between 7700-6200 cal BP (or longer) (West 1996b:552; Potter 2004a). The ${ }^{14} \mathrm{C}$ chronology developed here is used to evaluate these ambiguities.

\section{Previous Radiocarbon Syntheses}

This article represents the first comprehensive archaeological ${ }^{14} \mathrm{C}$ chronology for this region. Only a few well-known sites dominate the cultural historical literature for the region (Hamilton and Goebel 1999; Holmes 2001). Previous intersite comparisons focus primarily on late Pleistocene/ early Holocene archaeology with little attention to the middle and late Holocene period. The most influential compendium of ${ }^{14} \mathrm{C}$ data were numerous papers in West (1996a), but these were limited to components older than $\sim 7000 \mathrm{BP}$. These data were used widely in late Pleistocene/early Holocene reviews, focused primarily on the peopling of the Americas (West 1996b; Dilley 1998; Hamilton and Goebel 1999; Dixon 1999, 2001; Yesner 2001; Bever 2006). Mason et al. (2001) expanded parts of this sample, focusing on Denali complex sites in Alaska and Yukon Territory, but again only considered components older than $\sim 7000 \mathrm{BP}$. A comprehensive ${ }^{14} \mathrm{C}$ database was compiled and calibrated for the Copper River basin and surrounding highlands (Potter 1997), encompassing only a part of this study area.

\section{METHODS}

\section{Database Development, Variables, and Data Limitations}

This ${ }^{14} \mathrm{C}$ database was compiled from published articles, books, cultural resource reports, and theses, and does not include ongoing investigations where the results have not yet been published. The database includes $274{ }^{14} \mathrm{C}$ dates from 160 components at 113 sites (see Appendix). Component delineation followed the original investigators, with exceptions noted below. ${ }^{14} \mathrm{C}$ dates on cultural features were preferred over stratigraphic dates (e.g. Broken Mammoth Cultural Zone [CZ] 4). Bone apatite dates were not considered due to susceptibility of contamination, and soil organic (bulk sampled) dates were only considered if charcoal dates were unavailable. Dates determined to be discordant by the original investigator were not used (with a few exceptions, see below). Multiple dates on single stratigraphic contexts were averaged following Ward and Wilson (1978) using the CALIB v 5.0 program (Stuiver and Reimer 1993), providing a single age estimate. The age estimates were calibrated using CALIB v 5.0 with the IntCal04 terrestrial calibration curve (Reimer et al. 2004). Components were grouped into 1000-calendar yr intervals by the median of each date range to mitigate the lack of precision of single age estimators.

Variables gathered from the primary literature included lithic assemblage characteristics and associated fauna. To counter sample size effects, microblade technology, notched bifaces, and fauna, taxa were denoted as presence/absence. Space-averaging may be affected by environmental differences among subregions (Lyman 2003). Environmental variability in the study area is primarily affected by elevation, with the Tanana-Kuskokwim and Copper River lowlands currently dominated by boreal forests, contrasted with the foothills of the Alaska Range and Talkeetna Mountains dominated by moist and alpine tundra and dwarf and tall shrubs (Warhaftig 1965; Gallant et al. 1995). This dichotomy is evaluated by assigning values of "upland" and "lowland" to components in these 2 environments (the break is around $500 \mathrm{~m}$ asl). Five major subregions are distinguished within the study area; 2 primarily lowland areas currently dominated by boreal forest (Tanana and Copper 
River basins, areas below 500 and $1000 \mathrm{~m}$ asl, respectively), and 3 primarily upland areas dominated by moist and alpine tundra (Upper Nenana and Upper Susitna River valleys and the Tanana foothills/Tangle Lakes area) (Figure 1). Sites within the lower Nenana and Kantishna basins are included in the Tanana basin subregion. Sites within the Matanuska basin are included in the Upper Susitna subregion. Absolute elevation (in $\mathrm{m}$ asl) was derived from the 15-min digital elevation models (DEM) for Alaska (US Geological Survey 1979).

Components were grouped by time periods derived from transitions among cultural constructs within cultural historical sequences in order to assess broad levels of economic and technological change. Late Pleistocene (14,000-12,000 cal BP) comprises early complexes like Chindadn and Nenana, and is associated with glacial conditions ( $n=11$ components). Early Holocene $(12,000$ $6000 \mathrm{cal} \mathrm{BP}$ ) comprises the Denali complex, and is associated with the expansion of the boreal forest $(n=51$ components). Middle Holocene (6000-1000 cal BP) comprises the Northern Archaic tradition and Late Denali complex ( $n=76$ components). Late Holocene ( $<1000 \mathrm{cal} \mathrm{BP})$ comprises the Athabascan tradition ( $n=22$ components).

There are several limitations to these data, including cultural contexts, sampling, and taphonomic bias. Many components have associated stratigraphic dates or single dates on cultural features, both of which may reduce dating accuracy and precision. Over half of these components are dated through associated stratigraphic dates $(n=99,62 \%$ of the total), $54(34 \%)$ have dates associated with cultural features, and 7 (4\%) have unknown/unreported associations. Do these data constitute a representative sample of cultural components within the region? The question is difficult to answer, given the current level of understanding and the relative lack of integrative intersite variability studies (Potter 2005). Site discovery is directly related to sampling effort, which has largely followed development in the region. However, several linear transects cross the study area, oriented both east-west and north-south, providing checks against this bias (e.g. Cook 1977; Aigner and Gannon 1981a,b; Bowers et al. 1995; Potter et al. 2002, 2007a,b). Surveys have resulted in discovery of components from every period of human occupation in North America, and while investigator bias for earlier sites (more common as research topics) may factor here, a recent survey through the midTanana basin resulted in the discovery of 56 buried prehistoric components, 36 of them dated without bias for expected age (Potter et al. 2007b). This distribution generally matches the distribution of previously dated components, with some exceptions noted below.

Taphonomic bias favoring later components is difficult to evaluate without detailed geoarchaeological investigations. However, the exponential population curve peaking in the most recent interval predicted by Surovell and Brantingham (2007) in cases of taphonomic bias is not observed here (compare their Figure 2 with Figure 2, next page). For this reason, the dated components are used as proxies for paleodemography. However, due to the limitations discussed above, the patterns presented here should be seen as tentative pending further research on search image adequacy, stratified sampling, and regional geoarchaeology.

\section{Problematic Sites}

A number of sites presented problems in component delineation and age estimation, and for the sake of clarity and completeness, they are detailed here. Teklanika West possibly contains 3 components (Goebel et al. 1996), but the cultural material has not been demarcated on a stratigraphic basis (West 1996c), so I follow Mason et al. (2001) in only listing the earliest component (C1). The later Holocene dates from Donnelly Ridge (West 1967) and the Little Panguingue Creek hearth (Hoffecker and Powers 1996) are tentatively accepted here given their acceptance by other archaeologists (e.g. Shinkwin 1979:161-2), and lack of evidence for contamination. 


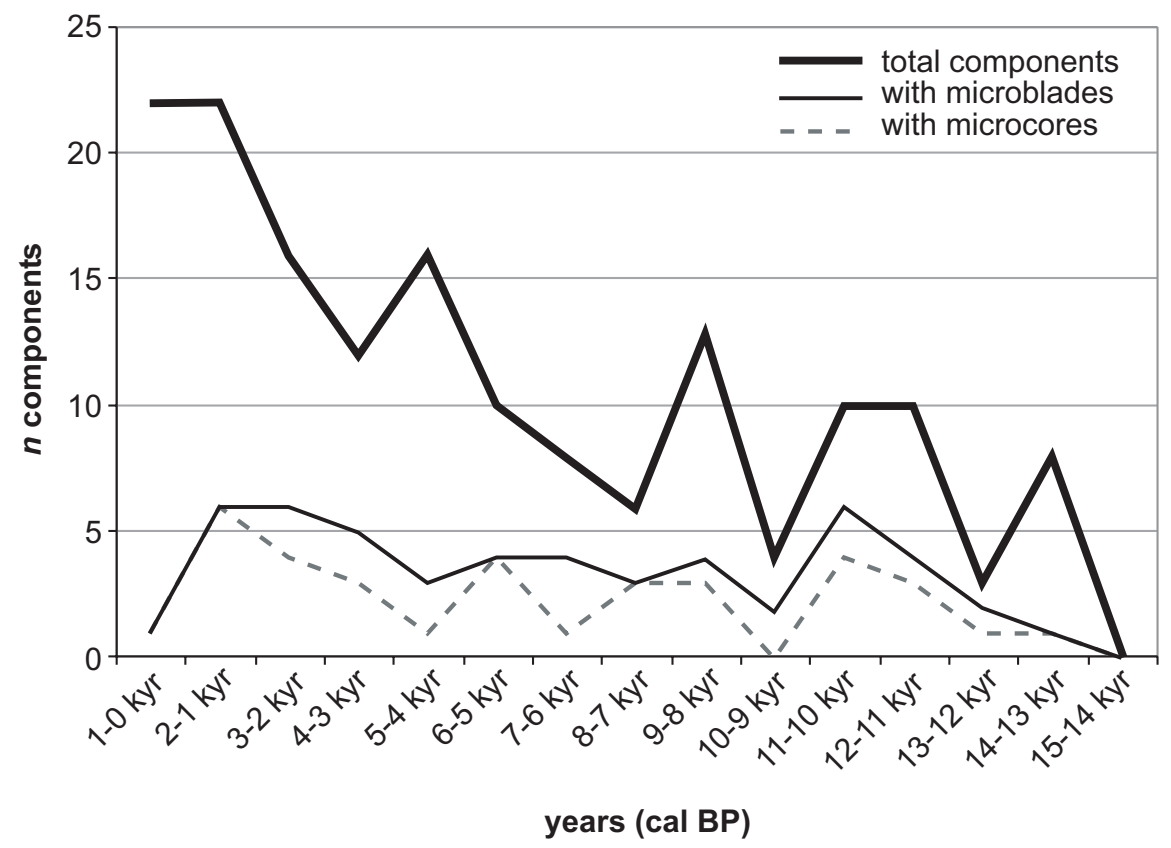

Figure 2 Distribution of component ages and associated technology per 1000-yr age interval (using median calibrated values).

Dry Creek C2 may be composed of multiple occupations (Mason et al. 2001), or Dry Creek C1 and C2 may be a single component with post-depositional disturbance (Thorson 2006). Here, Dry Creek C1 and C2 are considered 2 distinct components, following Powers et al. (1983). Dixon (1993:86) lists new ${ }^{14} \mathrm{C}$ dates for Jay Creek Ridge ( 9800 BP), but there is no report on context, so the dates in Dixon et al. (1985) are used here ( 7000 BP), following Mason et al. (2001). The chronologically older dates suggest the Upper Susitna area was habitable by at least 12,000 cal BP. West et al. (1996b:388) note that Whitmore Ridge Component 2 occurs in the A2b horizon, with 3 stratigraphically associated dates, 2 of which overlap. Though West et al. (1996b:393) suggest the dates are too young, they are consistent with the overall stratigraphy and ${ }^{14} \mathrm{C}$ chronology, and since no evidence for contamination is provided, the 2 overlapping dates are tentatively accepted here.

The ${ }^{14} \mathrm{C}$ record at Healy Lake Village site has been extensively discussed (Cook 1969, 1996; Erlandson et al. 1991; Dilley 1998). For this synthesis, only dates derived from charcoal are used for Levels 1-5. Cook (1996) defined 3 cultural stages at Healy Lake Village: Athabascan (Levels 1-3); Transitional (Levels 4-5); and Chindadn (Levels 6-10). These distinctions are kept for this synthesis, except that Level 1 is separated from Levels $2-3$, given a significantly younger hearth date in Level 1 and overlap of dates in Levels 2-3. Chindadn samples date between 11,400-8000 BP, with no correlation between depth and age. Though multiple occupations are likely, it is interpreted to be a single component dating to the average of charcoal dates, following Cook (1996).

\section{RESULTS}

\section{Radiocarbon Chronology}

Assuming component abundance reflects population size, the ${ }^{14} \mathrm{C}$-dated component distribution was used to estimate paleodemography. Figure 2 illustrates the absolute number of dated components per 
$1000 \mathrm{cal} \mathrm{yr}$ BP. The overall trend is a gradual increase in population to a peak of $2000-1000 \mathrm{cal}$ BP. The decrease in the final 1000-yr period reflects the reliance on typological dating during the protohistoric period (e.g. trade beads). At this low resolution, there are peaks and dips in component abundance. This distribution may be affected by sampling bias, particularly disproportional focus on sites of a certain age or stratigraphic setting. For example, the North Alaska Range project that resulted in the discovery and testing of numerous sites in the Upper Nenana Valley was designed to locate intact late Pleistocene landforms (Powers et al. 1983; Hoffecker 1985).

Recent linear surveys in the mid-Tanana basin, yielding 36 components dated without bias for expected age (Potter et al. 2007a,b), offer data to evaluate this possibility. Figure 3 shows component percentages for each interval based on all components from the 2006-2007 surveys ( $n=36$ components) compared with all previously known data $(n=124$ components compiled in Potter 2004a). The distributions are relatively similar except for relatively more sites in the early Holocene period (9000-5000 cal BP), and fewer sites in the mid to late Holocene (after $5000 \mathrm{cal} \mathrm{BP}$ ). The early Holocene period is often interpreted as a time of transition, from earlier Beringian technology and subsistence to boreal forest adaptations associated with the Northern Archaic tradition (Anderson and Douglas 1968; Dixon 1985; Clark 1994). Analysis of previous intersite data (Potter 2004a) indicated a possible hiatus in occupation in central Alaska between 7700-6200 cal BP (only 5 components were previously known from this period, $\sim 4 \%$ of the total). However, the new data set includes 6 components dating to this period (15\% of the new components), demonstrating the presence of human occupation of the region throughout the mid-late Holocene (Figure 2). Technological data indicates many aspects of technology (e.g. microblades, wedge-shaped microcores) were conserved through this period, thus linking the early and later Holocene microblade industries.

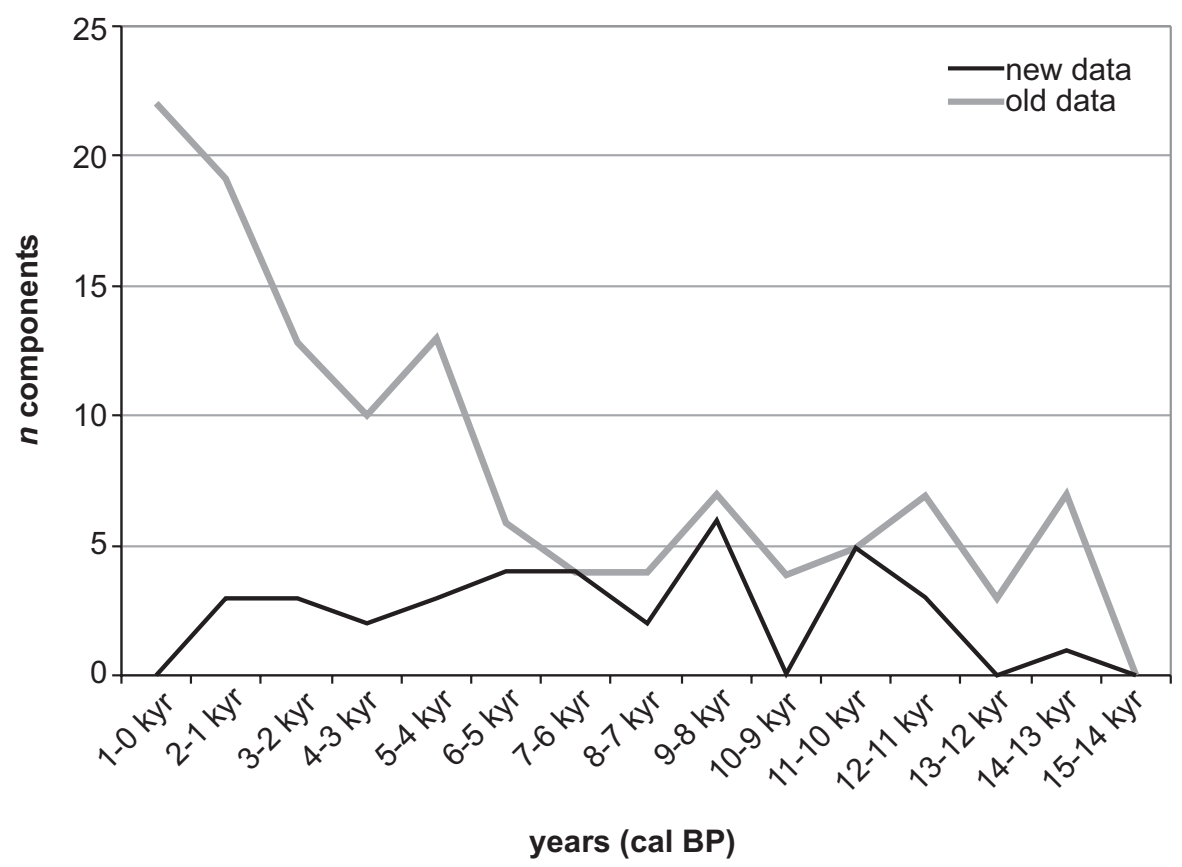

Figure 3 Comparison of component age distributions from recent surveys in the mid-Tanana basin (Potter et al. 2007a,b), labeled "new data," and from previous surveys (Potter 2004a), labeled "old data." 
The general similarity of these distributions suggests that these data are representative enough for exploration of this distribution as a proxy for paleo-population. After an initial peak at 14,000$13,000 \mathrm{cal} \mathrm{BP}$, representing the initial occupation of Alaska, the population dips for the next thousand-yr interval, rising again between 12,000-11,000 cal BP. The initial colonization event(s) have been discussed from many different perspectives (e.g. West 1981, 1996b; Powers and Hoffecker 1989; Hamilton and Goebel 1999; Dixon 2001; Holmes 2001; Yesner 2001; Bever 2006), and these dates support a correlation of early colonization with climate amelioration after $\sim 14,000$ cal BP, associated with the transition from herb tundra to shrub tundra (Ager and Brubaker 1985; Bigelow and Powers 2001).

The depopulation tracked at 13,000-12,000 cal BP correlates broadly to the Younger Dryas stadial, a cold period that is associated with glacial readvance (Bigelow and Edwards 2001). These data run counter to Bigelow and Powers (2001) and Mason et al. (2001), who noted no decrease in site occurrence during this period, but the latter examined only those sites associated with the Denali complex. This depopulation trend is, however, noted by Bever (2006:612), and importantly this pattern is reinforced here with a more widespread Alaska-wide context, indicating that the effects of the Younger Dryas may have been significant. Bever (2006:613) further notes that the diversity of the preYounger Dryas material contrasts with the single Denali complex technology after the Younger Dryas. The continuity of microcore and blade technology evidenced here could be explained by 1) continuity of regional populations using the same technology or 2) population replacement by microblade-using groups from outside the region (Siberia or northwest North America, see technology discussion below).

A second sharp population decrease is inferred for the 10,000-9000 cal BP interval, which might be correlated with the establishment of widespread spruce forests (Picea spp.) in the Tanana basin in the early Holocene. Kaufman et al. (2004:536) note the Holocene Thermal Maximum between 11,300-9100 cal BP in this region. West (1981:221-4) argues for an early Holocene peak and subsequent population crash as warming climate and growth of the boreal forest decimated Denali complex populations. The peak at $9000-8000 \mathrm{cal} \mathrm{BP}$ is harder to correlate with broader climate or vegetation changes. Mason et al. (2001) examined a selection of early Holocene Denali complex components in Alaska and the Yukon Territory, and their date distribution is relatively similar to the one presented here between 10,000-8000 cal BP. They interpret the spike at 9000-8000 cal BP as increased occupation associated with a cooling event at $\sim 8200$ cal BP (Klitgaard-Kristensen et al. 1998) due to increased abundance of caribou (Mason et al. 2001:539). However, faunal analysis using a much larger data set indicates that caribou hunting becomes more dominant after $\sim 5000 \mathrm{cal}$ BP (see below, Potter 2008).

The mid-late Holocene (after $6000 \mathrm{cal} \mathrm{BP}$ ) is generally characterized with increasing population, especially after $3000 \mathrm{cal} \mathrm{BP}$. The greater relative abundance of sites could also be due to increased archaeological visibility or a biased search image. While no known significant climate or vegetation change is known for this period, new technology and artifact types enter the region (including sidenotched biface forms, notched cobbles, and tabular microblade cores) (Cook and McKennan 1970; Dixon 1985). However, older technologies were also conserved and were used alongside the new forms (i.e. wedge-shaped microblade core forms). While the archaeological data could support partial population replacement (Dumond 1969; Workman 1978) or diffusion (Clark 1994), the component distribution may reflect an effective adaptation to the boreal forest (probably through a combination of new technology and new settlement and subsistence strategies). 


\section{Regional Chronologies}

Different land-use strategies are apparent in the component distributions. Figure 4 illustrates component ages for the 3 upland and 2 lowland areas in the study area. The Tanana basin subregion was largely unglaciated during the late Pleistocene (Kaufman and Manley 2004), and the northern foothills of the Alaska Range (Upper Nenana and Tanana foothills/Tangle Lakes subregions) were first occupied during the late Pleistocene, between 13,000-12,000 cal BP. The Upper Susitna was first occupied by $\sim 8000$ cal BP (or $\sim 11,400$ cal BP if the early dates in Dixon [1993:86] are considered). The Copper basin was dominated by the glacier-dammed Lake Atna until 11,600-9700 cal BP (Ferrians 1989:87), but the earliest known components date to $\sim 2500$ cal BP.

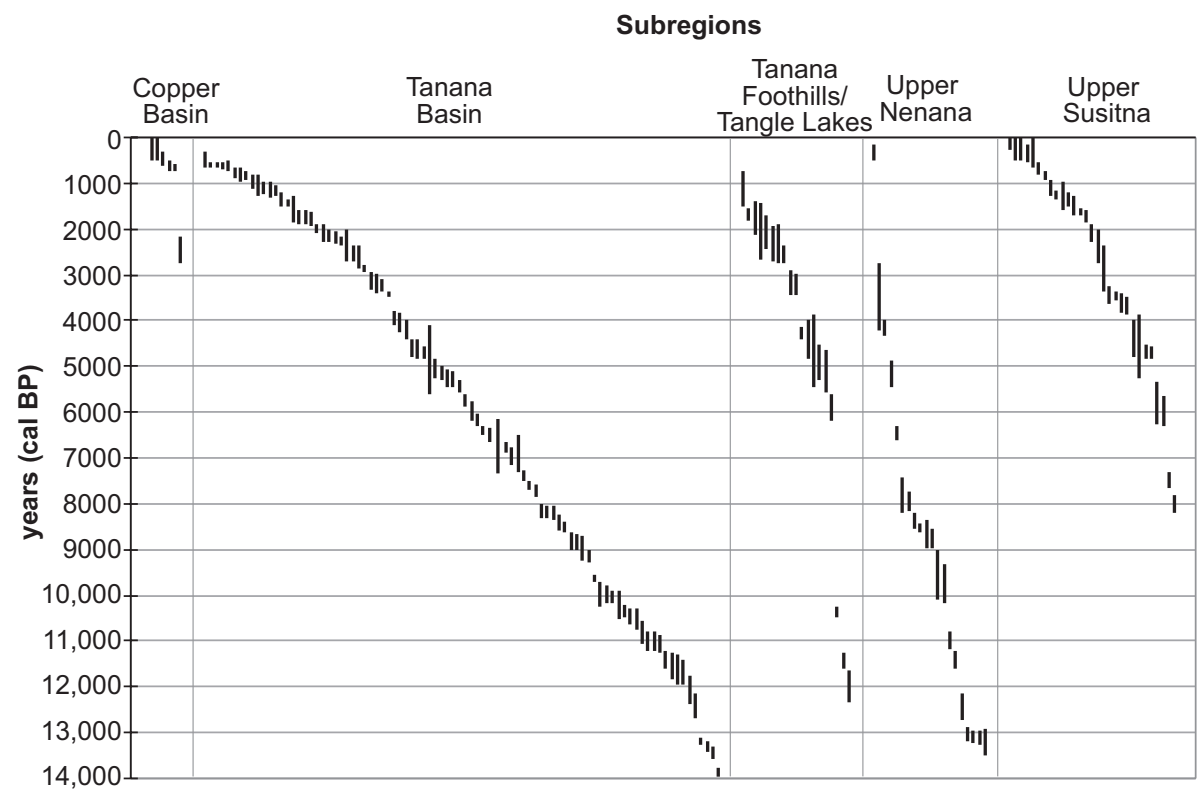

Figure 4 Component calibrated age ranges $(2 \sigma)$, ordered by median age estimator and subregion

The upland areas are differentially occupied through time, comprising $32 \%$ of early Holocene components, $53 \%$ of middle Holocene components, and $36 \%$ of late Holocene components (the late Pleistocene is not considered since some of the upland areas were not yet ice-free). Elevation data for each component confirms this pattern (Figure 5). Early Holocene components average $424 \pm 187$ $\mathrm{m}$ asl $($ median $=361)$ compared with $522 \pm 243 \mathrm{~m}$ asl $($ median $=487)$ for middle Holocene and $462 \pm 206 \mathrm{~m}$ asl (median $=487$ ) for late Holocene components. Average elevation values are significantly different between early and middle Holocene components ( $t$ test for independent samples, $t=$ $-2.42, d f=25, p=0.017)$, whereas middle and late Holocene components have similar distributions of sites relative to elevation $(t=1.05, d f=96, p=0.294)$. Average elevation values are similar between the late Pleistocene and early Holocene occupations $(t=-0.89, d f=60, p=0.377)$, indicating similar land-use strategies in the early Holocene associated with lowland areas, even after upland areas were deglaciated.

While the Tanana subregion has a continuous record with no major breaks, there are several breaks in the upland subregions (Figure 4). These upland areas all have chronological gaps between 7700$6200 \mathrm{cal} \mathrm{BP}$, and the fact that this is replicated in all 3 upland regions may indicate widespread 


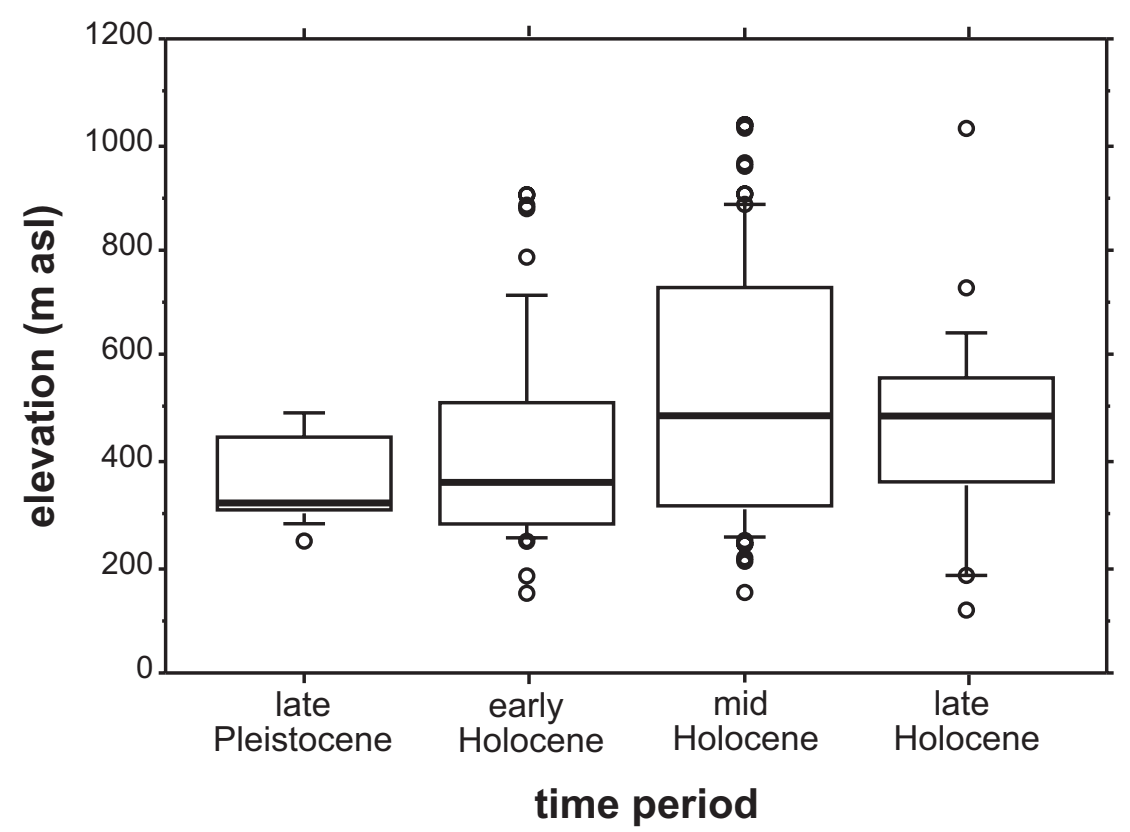

Figure 5 Box plots of elevation by time period

changing land-use strategies in the early to middle Holocene, rather than sampling bias. Consequently, the increased use of upland areas seen after $\sim 6200 \mathrm{cal} \mathrm{BP}$, along with new technologies associated with the Northern Archaic tradition, likely reflects new land-use strategies linked with seasonal caribou exploitation, and is consistent with increased numbers of components with caribou remains during this period (see below, Potter 2008). Shorter chronological gaps between 4000-3000 cal BP in the Tangle Lakes area may be artifacts of small sample size or changes in population or land-use strategies.

\section{DISCUSSION}

\section{Technological Continuity}

These ${ }^{14} \mathrm{C}$-dated component age estimates provide baseline data useful for a variety of purposes, including assessing technological and subsistence change and estimating paleo-population change. Continuity of microblade technology is readily apparent, as demonstrated in Figure 2. This not only includes microblades as products of this technology, but also particular core forms, including wedge-shaped microcores with associated core tablets rejuvenation (Holmes 2001, 2004; Yesner and Pearson 2002; see also Bowers 1999). Microblade technology generally parallels overall component abundance throughout the Holocene until 1000 cal BP.

In the earliest period (14,000-13,000 cal BP), there is 1 microblade-bearing component (Swan Point CZ4) and 7 non-microblade-bearing components. However, only 5 of the latter have more than $14 \mathrm{~m}^{2}$ excavated - and of these, only Walker Road C1 contains more than 39 retouched pieces. Powers and Hoffecker (1989) posited a non-microblade Nenana complex on the basis of some of these sites, but since then, Chindadn points (diagnostic to that complex) have been found associated with microblades at Swan Point CZ3 (Holmes 2008) and Broken Mammoth CZ3 (Krasinski 2005:32). This supports the contention that Chindadn points and microblades associated at Healy Lake (Cook 
1996) are not from mixed contexts as has been suggested (Hoffecker et al. 1993). One may argue that the relatively low frequencies of microblades in Swan Point CZ3 $(n=37)$ and Broken Mammoth CZ3 ( $n=44)$ (Krasinski 2005; Holmes 2008) suggest stratigraphic mixing; however, at Gerstle River C3, several contemporaneous and spatially discrete lithic clusters contain microblades at varying frequencies (between 1 and 242, comprising 2\% to 29\% of total debitage; Potter 2005). This variation could be due to many factors, including activity area differences or the tendency for microblades to be deposited in small discrete loci, easily missed depending on sampling strategies. The point here is that microblades are present in sites assigned to the both Nenana and Denali complexes. This is consistent with the hypothesis that Nenana and Denali complexes represent different portions of a single late Pleistocene technological tradition (West 1996b; Holmes 2001).

After 13,000 cal BP, these data suggest that microblades represent a conservative technology that was well suited to coping with climatic oscillations at the Pleistocene/Holocene transition as well as the expanding boreal forest. Increased upland exploitation in the mid-Holocene seems related to subsistence/settlement strategy changes given the opportunity for exploitation in earlier periods. This coincides with the introduction of cultural material like notched bifaces and notched pebbles, associated with the Northern Archaic tradition (Anderson and Douglas 1968; Dixon 1985). These data show that along with this new technology, early Holocene and middle Holocene populations used the landscape in different ways, partially reflected in increased upland use, but also in faunal assemblage differences (see next section).

\section{Economic Change}

Of the 160 components in this study, 87 contain faunal remains (54\% of total). Of these 87 components, 26 have fragmented, burned, and calcined fragments that are not analyzed further. The remaining 62 components (39\% of total) provide a record for subsistence economies. Table 1 summarizes the variability in faunal presence/absence among components for each time period. Only those taxa present at $>5$ components are included. Large and small mammal categories follow from the original investigators. The late Pleistocene period is somewhat skewed by the Broken Mammoth CZ4 assemblage, which contains almost all of the listed taxa (Yesner 1996), and the generally small sample size from the Late Pleistocene $(n=5)$ should be considered.

While these data are very coarse grained ( NISP is not used), significant patterning is evident. Bison and wapiti occurrence within archaeological assemblages decrease through time, whereas caribou and to a lesser extent moose increases. The sharpest break is between the early and middle Holocene (6000 cal BP). Most small and medium mammals appear in relatively more assemblages in the middle and late Holocene, particularly hare and canids. Fish are also more common in the later Holocene, but interestingly, birds are more common in the Late Pleistocene. These patterns indicate changes in subsistence economies consistent with the land-use patterns noted above. Both of these data sets indicate a shift from a broad subsistence base using primarily lowland areas incorporating bison and wapiti in the late Pleistocene and early Holocene to acquisition of more seasonally abundant game (caribou, fish) in the middle and late Holocene. The growing importance of caribou is reflected in increasing use of upland areas like the Upper Susitna Valley, where faunal assemblages are dominated by caribou remains.

\section{Cultural History}

Given these component age distributions, a modification of current cultural historical sequences may be in order. While late Pleistocene material may reflect considerable diversity, the East Beringian tradition proposed by Holmes (2001) may adequately encompass this variability, given that 
Table 1 Faunal patterning by time period; cells represent percentages of total components per time period with at least 1 specimen of each taxonomic classification.

\begin{tabular}{|c|c|c|c|c|}
\hline $\begin{array}{l}\text { Taxa (number of } \\
\text { components where } \\
\text { they occur) }\end{array}$ & $\begin{array}{l}\text { Late Holocene } \\
(0-1000 \text { cal BP }) \\
n=16\end{array}$ & $\begin{array}{l}\text { Middle Holocene } \\
(1000-6000 \text { cal BP }) \\
n=26\end{array}$ & $\begin{array}{l}\text { Early Holocene } \\
(6000-12,000 \text { cal BP }) \\
n=14\end{array}$ & $\begin{array}{l}\text { Late Pleistocene } \\
(12,000-14,000 \text { cal BP) } \\
n=5\end{array}$ \\
\hline \multicolumn{5}{|l|}{ General Size Classes } \\
\hline L mammal $(n=59)$ & $94 \%$ & $88 \%$ & $100 \%$ & $100 \%$ \\
\hline S mammal $(n=28)$ & $56 \%$ & $50 \%$ & $29 \%$ & $40 \%$ \\
\hline \multicolumn{5}{|l|}{ Ungulates } \\
\hline Caribou $(n=29)$ & $63 \%$ & $58 \%$ & $21 \%$ & $20 \%$ \\
\hline Moose $(n=15)$ & $31 \%$ & $23 \%$ & $21 \%$ & $20 \%$ \\
\hline Bison $(n=8)$ & $0 \%$ & $4 \%$ & $36 \%$ & $40 \%$ \\
\hline Wapiti $(n=7)$ & $0 \%$ & $0 \%$ & $29 \%$ & $60 \%$ \\
\hline Sheep $(n=7)$ & $13 \%$ & $0 \%$ & $21 \%$ & $40 \%$ \\
\hline \multicolumn{5}{|l|}{ Other Mammals } \\
\hline Hare $(n=15)$ & $38 \%$ & $23 \%$ & $14 \%$ & $20 \%$ \\
\hline Beaver $(n=11)$ & $13 \%$ & $27 \%$ & $7 \%$ & $20 \%$ \\
\hline Canid $(n=9)$ & $31 \%$ & $8 \%$ & $7 \%$ & $20 \%$ \\
\hline $\operatorname{Bear}(n=6)$ & $13 \%$ & $12 \%$ & $7 \%$ & $0 \%$ \\
\hline \multicolumn{5}{|l|}{ Birds and Fish } \\
\hline Birds $(n=13)$ & $19 \%$ & $15 \%$ & $21 \%$ & $60 \%$ \\
\hline Fish $(n=13)$ & $31 \%$ & $23 \%$ & $7 \%$ & $20 \%$ \\
\hline
\end{tabular}

material diagnostic to both Nenana and Denali complexes are found intermixed. Between $\sim 12,000$ $6000 \mathrm{cal} \mathrm{BP}$, the archaeology is dominated by cultural material assigned to the Denali complex (or Paleoarctic tradition). The Northern Archaic tradition, typically dated between 6000-3500 cal BP in this region (Dixon 1985), should be extended to $\sim 1000 \mathrm{cal}$ BP on the basis of continuity of lithic types and basic settlement patterns. A distinct Late Denali complex (Holmes 1977; Dixon 1985) is unnecessary, given the continuity of microblade technology. The well-known transformation in settlement, site structure, and technology associated with the Athabascan tradition (Shinkwin 1977, 1979; Clark 1981; Dixon 1985) occurred in this region between 1300-800 cal BP, tentatively dated to $\sim 1000 \mathrm{cal} \mathrm{BP}$. This transition is explored in detail in Potter (forthcoming).

These data demonstrate continuity in certain technological elements along with economic and settlement system changes. Cultural historical constructs as currently developed on the basis of lithic typology alone may not be adequate to explain this cultural change. Rather, these cultural changes appear to relate more to variation in settlement, mobility, and subsistence systems. Potential avenues for exploring this diverse record involve analyzing site location, site structure, and organization, along with more traditional data sets like lithic typology and faunal remains. In this context, identification and description of recurring depositional and activity sets will be useful. Understanding how tools and toolkits were used as part of adaptive systems, incorporating settlement strategies and subsistence economies within a logistical and residential mobility system will result in more robust explanations of cultural change in this region.

\section{ACKNOWLEDGMENTS}

A synthetic treatment of ${ }^{14} \mathrm{C}$ data is only possible due to the efforts of the original investigators (referenced in Appendix Table A1), and I thank them collectively for their efforts. Joshua Reuther, Chuck Holmes, John Cook, Peter Bowers, Bill Workman, Tom Gillispie, Craig Gerlach, and others provided valuable comments on earlier iterations of this research. Diane Hanson, Joan Dale, and 
researchers at the US Bureau of Indian Affairs Office provided assistance in tracking down information on some of these dates. Partial funding for this work was provided by a Wenner-Gren Hunt Post-doctoral Fellowship.

\section{REFERENCES}

Ackerman RE. 2004. The Northern Archaic tradition in southwestern Alaska. Arctic Anthropology 41(2):15362.

Ager TA, Brubaker LB. 1985. Quaternary palynology and vegetational history of Alaska. In: Bryant VM, Holloway RG, editors. Pollen Records of Late Quaternary North American Sediments. Dallas: American Association of Stratigraphic Palynologists. p 353-84.

AHRS (Alaska Heritage Resource Survey). n.d. Site cards on file at the Alaska Office of History and Archaeology, Anchorage.

Aigner JS, Gannon BL. 1981a. Archaeological survey in interior Alaska: final report on the 1980 archaeological survey along the Northwest Alaska Pipeline Company proposed natural gas pipeline corridor from Prudhoe Bay to Delta Junction, with additional work to the south. November, 1981. Fairbanks: Anthropology Program and Institute of Arctic Biology, University of Alaska.

Aigner JS, Gannon BL. 1981b. Archaeological survey in interior Alaska: final report on the 1981 archaeological survey along the Northwest Alaska Pipeline Company proposed natural gas pipeline corridor from Prudhoe Bay to Delta Junction, with additional work to the south. December, 1981. Fairbanks: Anthropology Program and Institute of Arctic Biology, University of Alaska.

Amsden CW. 1977. A quantitative analysis of Nunamiut Eskimo settlement dynamics: 1898-1969 [PhD dissertation]. Albuquerque: University of New Mexico. $391 \mathrm{p}$.

Anderson DD. 1968. A Stone Age campsite at the gateway to America. Scientific American 218(6):24-33.

Bacon GH. 1977. The prehistory of Alaska: a speculative alternative. In: Helmer JW, Van Dyke S, Kense FJ, editors. Problems in the Prehistory of the North American Subarctic: The Athapaskan Question. Calgary: University of Calgary Archaeological Association. p $1-10$.

Bacon GH, Holmes CE. 1980. Archaeological survey and inventory of cultural resources at Fort Greely, Alaska, 1979. ALASKARCTIC. Report submitted to the US Army Corps of Engineers, Alaska District, Contract No. DAC85-78-C-0045.

Betts RC. 1987. Archaeological investigations at Butte Lake, Alaska: a report to the University of Alaska Museum Geist Fund. Report on file at the Alaska Office of History and Archaeology, Anchorage.

Bever MR. 2006. Too little, too late? The radiocarbon chronology of Alaska and the peopling of the New World. American Antiquity 71(4):595-620.
Bigelow NH, Edwards ME. 2001. A 14,000 yr paleoenvironmental record from Windmill Lake, central Alaska: Lateglacial and Holocene vegetation in the Alaska range. Quaternary Science Reviews 20(1-3): 203-15.

Bigelow NH, Powers WR. 1994. New AMS dates from the Dry Creek Paleoindian site, central Alaska. Current Research in the Pleistocene 11:114-15.

Bigelow NH, Powers WR. 2001. Climate, vegetation, and archaeology 14,000-9000 cal yr BP in central Alaska. Arctic Anthropology 38(2):171-95.

Binford LR. 1977. Forty-seven trips: a case study in the character of some formation processes of the archaeological record. In: Hall ES Jr, editor. Contributions to Anthropology: The Interior Peoples of Northern Alaska. National Museum of Man Mercury Series, Archaeological Survey of Canada Paper No. 49. Ottawa: National Museums of Canada. p 299-351.

Binford LR. 1978. Nunamiut Ethnoarchaeology. New York: Academic Press. 521 p.

Binford LR. 1980. Willow smoke and dogs' tails: huntergatherer settlement systems and archaeological site formation. American Antiquity 45(1):4-20.

Binford LR. 1983. Working at Archaeology. New York: Academic Press. 463 p.

Binford LR. 1991. When the going gets tough, the tough get going: Nunamiut local groups, camping patterns and economic organization. In: Gamble CS, Boismier WA, editors. Ethnoarchaeological Approaches to Mobile Campsites. Ann Arbor: International Monographs in Prehistory, Ethnoarchaeological Series 1. p 25-137.

Bowers PM. 1980. The Carlo Creek site: geology and archaeology of an early Holocene site in the central Alaska range. Anthropology and Historic Preservation Cooperative Park Studies Unit Occasional Paper 27. Fairbanks: University of Alaska Fairbanks.

Bowers PM. 1999. AMS dating of the Area 22 American Paleoarctic tradition microblade component at the Lisburne site, Arctic Alaska. Current Research in the Pleistocene 16:12-4.

Bowers PM, Mason OK, Ludwig SL, Higgs AS, Smythe CW. 1995. Cultural resources inventory and assessment of the proposed Healy to Fairbanks Northern Intertie, South Route and Tanana Flats alternatives. Report submitted to Golden Valley Electric Association, Fairbanks. Northern Land Use Research, Inc., Fairbanks. NLUR Technical Report No. 30.

Carr C. 1985. Alternate models, alternate techniques: variable approaches to intrasite spatial analysis. In: Carr C, editor. For Concordance in Archaeological Analysis: Bridging Data Structure, Quantitative Tech- 
nique, and Theory. Kansas City: Westport Press. p 302-473.

Clark DW. 1981. Prehistory of the western Subarctic. In: Helm J, editor. Handbook of North American Indians, Volume 6, Subarctic. Washington DC: Smithsonian Institution Press. p 107-29.

Clark DW. 1994. The Archaic in the extreme Northwest of North America. Revista de Arqueología Americana 5:71-99.

Clark DW. 2001. Microblade-culture systematics in the far interior Northwest. Arctic Anthropology 38(2):6480.

Clark GH. 1974. Archaeological survey and excavation along the southernmost portion of the Trans-Alaska Pipeline system. Final report to the Alyeska Pipeline Service Company, Anchorage.

Cook JP. 1969. The early prehistory of Healy Lake, Alaska [PhD dissertation]. Madison: University of Wisconsin.

Cook JP. 1975. Archaeology of interior Alaska. Western Canadian Journal of Anthropology 3-4:125-33.

Cook JP, editor. 1977. Pipeline Archeology. Final Report. Fairbanks: University of Alaska.

Cook JP. 1996. Healy Lake. In: West FH, editor. American Beginnings: The Prehistory and Palaeoecology of Beringia. Chicago: University of Chicago Press. p 323-7.

Cook JP, Gillispie TE. 1986. Notched points and microblades. Paper presented at the 13th Annual Meeting of the Alaska Anthropological Association, Fairbanks, Alaska.

Cook JP, McKennan RA. 1970. The Athapaskan tradition: a view from Healy Lake in the Yukon-Tanana Upland. Paper presented at the 10th Annual Meeting of the Northeastern Anthropological Association, Ottawa.

Cook JP, Newell RR, Wiersum WE. 1977. Hogan's Hill to Salcha River. In: Cook JP, editor. Pipeline Archeology. Final Report. Fairbanks: University of Alaska. p 70-180.

Dilley TE. 1998. Late Quaternary loess stratigraphy, soils, and environments of the Shaw Creek Flats paleoindian sites, Tanana Valley, Alaska [PhD dissertation]. Tucson: University of Arizona.

Dixon EJ. 1985. Cultural chronology of central interior Alaska. Arctic Anthropology 22(1):47-66.

Dixon EJ. 1993. Quest for the Origins of the First Americans. Albuquerque: University of New Mexico Press. $160 \mathrm{p}$.

Dixon EJ. 1999. Bones, Boats, and Bison: Archeology and the First Colonization of Western North America. Albuquerque: University of New Mexico Press. 336 p.

Dixon EJ. 2001. Human colonization of the Americas: timing, technology and process. Quaternary Science Reviews 20(1-3):277-99.

Dixon EJ, Smith GS, Andrefsky W Jr, Saleeby B, Utermohle CJ. 1985. Susitna Hydroelectric Project cul- tural resource investigations: 1979-1985. Report prepared for the Alaska Power Authority by University of Alaska Museum, University of Alaska, Fairbanks.

Dixon EJ, Smith GS, Plaskett D. 1980. Archaeological survey and inventory of cultural resources, Fort Wainwright, Alaska. Prepared for US Army Corps of Engineers, Alaska District.

Dumond DE. 1969. Toward a prehistory of the Na-Dene, with a general comment on population movements among nomadic hunters. American Anthropologist 71(5):857-63.

Enloe JG. 1993. Ethnoarchaeology of marrow cracking: implications for the recognition of prehistoric subsistence organization. In: Hudson J, editor. From Bones to Behavior: Ethnoarchaeological and Experimental Contributions to the Interpretation of Faunal Remains. Center for Archaeological Investigations, Occasional Paper No. 21. Carbondale: Southern Illinois University.

Erlandson J, Walser R, Maxwell H, Bigelow N, Cook J, Lively R, Adkins C, Dodson D, Higgs A, Wilber J. 1991. Two early sites of eastern Beringia: context and chronology in Alaska interior archaeology. Radiocarbon 33(1):35-50.

Ferrians Jr OJ. 1989. Glacial Lake Atna, Copper River Basin, Alaska. In: Carter LD, Hamilton TD, Galloway JP. Late Cenozoic History of the Interior Basins of Alaska and the Yukon. Washington, DC: United States Geological Survey Circular 1026. p 85-8.

Gallant AL, Binnian EF, Omernik JM, Shasby MB. 1995. Ecoregions of Alaska. United States Geological Survey Professional Paper 1567. Washington, DC: US Government Printing Office.

Gerlach SC, Steffian AF, Vinson DM, Jordan JW, Molina DJ. 1989. Over-the-horizon backscatter Alaska radar system. Report of 1989 archaeological investigations of the Tok and Gulkana study areas, Alaska. Occasional Papers in Archaeology No. 1(1). Fairbanks: University of Alaska Museum.

Goebel TE, Powers WR, Bigelow NH, Higgs AS. 1996. Walker Road. In: West FH, editor. American Beginnings: The Prehistory and Palaeoecology of Beringia. Chicago: University of Chicago Press. p 356-63.

Grayson DK, Meltzer DJ. 2002. Clovis hunting and large mammal extinction: a critical review of the evidence. Journal of World Prehistory 16(4):313-59.

Hamilton TD, Goebel TE. 1999. Late Pleistocene peopling of Alaska. In: Bonnichsen R, Turnmire KL, editors. Ice Age Peoples of North America: Environments, Origins, and Adaptations. Corvallis: Oregon State University Press. p 156-99.

Hanson DK. 1999. Interim report of archaeological activities at the Ringling material site (MS-71-2-020-5), Gulkana, Alaska. Report on file at the Office of History and Archaeology, Anchorage.

Higgs AS, Potter BA, Bowers PM, Mason OK. 1999. Cultural resource survey of the Yukon training area and 
Fort Greely Army lands withdrawal, Alaska. ABR, Inc. and US Army Cold Regions Research and Engineering Laboratory. Northern Land Use Research, Inc., Fairbanks. NLUR Technical Report No. 66.

Hoffecker JF. 1985. North Alaska Range Early Man Project: archaeological field research: 1980. In: Swanson $\mathrm{W}$, editor. On research and exploration projects supported by the National Geographic Society, for which an initial grant or continuing support was provided in the year 1978. National Geographic Society Research Reports 19:48-59.

Hoffecker JF, Powers WR. 1996. Little Panguingue Creek. In: West FH, editor. American Beginnings: The Prehistory and Palaeoecology of Beringia. Chicago: University of Chicago Press. p 371-4.

Hoffecker JF, Powers WR, Goebel T. 1993. The colonization of Beringia and the peopling of the New World. Science 259(5091):46-53.

Hofman JL, Todd LC. 2001. Tyranny in the archaeological record of specialized hunters. In: Gerlach SC, Murray MS, editor. People and Wildlife in Northern North America: Essays in Honor of R. Dale Guthrie. BAR International Series 944. Oxford: British Archaeological Reports. p 200-15.

Holmes CE. 1977. 3000 years of prehistory at Minchumina: the question of cultural boundaries. In: Helmer JW, Van Dyke S, Kense FJ, editors. Problems in the Prehistory of the North American Subarctic: The Athapaskan Question. Calgary: University of Calgary Archaeological Association. p 11-5.

Holmes CE. 1986. Lake Minchumina Prehistory: An Archaeological Analysis. Anchorage: Alaska Anthropological Association Monograph Series, Aurora 2. $176 \mathrm{p}$.

Holmes CE. 1988. An early post paleo-Arctic site in the Alaska Range. Paper presented at the 15th Annual Meeting of the Alaska Anthropological Association, Fairbanks.

Holmes CE. 1996. Broken Mammoth. In: West FH, editor. American Beginnings: The Prehistory and Paleoecology of Beringia. Chicago: University of Chicago Press. p 312-8.

Holmes CE. 2001. Tanana River Valley archaeology circa 14,000 to 9000 BP. Arctic Anthropology 38(2): 154-70.

Holmes CE. 2004. Pre-Clovis traces at Swan Point, Alaska: early Americans in eastern Beringia. Interview given to Floyd Largent, Jr. Mammoth Trumpet 20(1):4-7.

Holmes CE. 2008. Swan Point: technology of the Beringian period in Alaska. Paper presented at the 73rd annual meeting of the Society for American Archaeology, Vancouver.

Holmes CE, VanderHoek R, Dilley TE. 1996. Swan Point. In: West FH, editor. American Beginnings: The Prehistory and Paleoecology of Beringia. Chicago: University of Chicago Press. p 319-23.
Kaufman DS, Manley WF. 2004. Pleistocene maximum and Late Wisconsinan glacier extents across Alaska, USA. In: Ehlers J, Gibbard PL, editor. Quaternary Glaciations - Extent and Chronology, Volume 2: Part II: North America. Developments in Quaternary Sciences 2. Amsterdam: Elsevier. p 9-28.

Kaufman DS, Ager TA, Anderson NJ, Anderson PM, Andrews JT, Bartlein PJ, Brubaker LB, Coats LL, Cwynar LC, Duvall ML, Dyke AS, Edwards ME, Eisner WR, Gajewski K, Geirsdóttir A, Hu FS, Jennings AE, Kaplan MR, Kerwin MW, Lozhkin AV, MacDonald GM, Miller GH, Mock CJ, Oswald WW, OttoBliesner BL, Porinchu DF, Rühland K, Smol JP, Steig EJ, Wolfe BB. 2004. Holocene thermal maximum in the western Arctic $\left(0-180^{\circ} \mathrm{W}\right)$. Quaternary Science Reviews 23(5-6):529-60.

Klitgaard-Kristensen D, Sejrup HP, Haflidason H, Johnsen S, Spurk M. 1998. A regional 8200 cal. yr BP cooling event in northwest Europe, induced by final stages of the Laurentide ice-sheet deglaciation? Journal of Quaternary Science 13(2):165-9.

Krasinski KE. 2005. Intrasite spatial analysis of Late Pleistocene/Early Holocene archaeological material from the Broken Mammoth site [MA thesis]. Anchorage: University of Alaska Anchorage.

Lively RA. 1996. Chugwater. In: West FH, editor. American Beginnings: The Prehistory and Paleoecology of Beringia. Chicago: University of Chicago Press. p 308-11.

Lyman RL. 2003. The influence of time averaging and space averaging on the application of foraging theory in zooarchaeology. Journal of Archaeological Science 30(5):595-610.

Maitland RE. 1986. The Chugwater site (FAI-035), Moose Creek Bluff, Alaska. Final report, 1982 and 1983 seasons. Unpublished report on file, US Army Corps of Engineers, Alaska District, Anchorage.

Mason OK, Bowers PM, Hopkins DM. 2001. The early Holocene Milankovitch thermal maximum and humans: adverse conditions for the Denali complex of eastern Beringia. Quaternary Science Reviews 20(13):525-48.

McKay JE. 1981. Cultural resource investigations of the Denali Highway Project. In: Gibson DE, editor. Archaeological Survey Projects, 1979. Miscellaneous Publications, History and Archaeology Series 28. Anchorage: Alaska Office of History and Archaeology. p 201-36.

Mobley CM. 1982. The Landmark Gap Trail site, Tangle Lakes, Alaska: another perspective on the Amphitheater Mountain complex. Arctic Anthropology 19(1): 81-102.

Mobley CM. 1991. The Campus Site: A Prehistoric Camp at Fairbanks, Alaska. Fairbanks: University of Alaska Press. 104 p.

Pearson GA. 1999. Early occupations and cultural sequence at Moose Creek: a Late Pleistocene site in cen- 
tral Alaska. Arctic 52(4):332-45.

Phippen PG. 1988. Archaeology at Owl Ridge: a Pleistocene-Holocene boundary age site in central Alaska [MA thesis]. Fairbanks: University of Alaska Fairbanks.

Plaskett D. 1977. The Nenana Gorge site: a late prehistoric Athabaskan campsite in central Alaska [MA thesis]. Fairbanks: University of Alaska Fairbanks.

Potter BA. 1997. A first approximation of Ahtna region archaeology [MA research paper]. Fairbanks: University of Alaska Fairbanks.

Potter BA. 2001. Recent investigations at the Gerstle River site, a multicomponent site in central Alaska. Current Research in the Pleistocene 18:52-4.

Potter BA. 2004a. Modeling intersite variability in interior Alaska: overcoming conceptual ambiguity through pattern recognition. Paper presented at the 69th Annual Meeting of the Society for American Archaeology, Montreal, Canada.

Potter BA. 2004b. Cultural resources survey of proposed seismic survey lines near Nenana, Alaska. Prepared for Andex Resources, LLC, by Northern Land Use Research, Inc., Fairbanks. NLUR Technical Report No. 253.

Potter BA. 2005. Site structure and organization in central Alaska: archaeological investigations at Gerstle River [PhD dissertation]. Fairbanks: University of Alaska Fairbanks.

Potter BA. 2008. A first approximation of interassemblage variability in central Alaska. Arctic Anthropology.

Potter BA. Forthcoming. Exploratory models of intersite variability in mid-late Holocene central Alaska. Arctic.

Potter BA, Bowers PM, Wooley CB, Gallison JD, Sheppard WL, Gelvin-Reymiller C, Reuther JD. 2002. Results of the 2001 Phase I Cultural Resources Survey of the proposed Alaska Gas Pipeline Project area, Southern Route. Report prepared for Alaska Gas Producers Pipeline Team by Northern Land Use Research, Inc., Fairbanks, and Chumis Cultural Resource Services, Anchorage. NLUR Technical Report No. 147.

Potter BA, Gaines EP, Bowers PM, Proue M. 2007a. Results of the 2006 Cultural Resource Survey of proposed Alaska Railroad Northern Rail extension routes and ancillary facilities, Alaska. Report prepared for ICF International. Northern Land Use Research, Inc., Fairbanks.

Potter BA, Reuther JD, Bowers PM, Gelvin-Reymiller C. 2007b. Results of the 2007 Cultural Resource Survey of proposed Alaska Railroad Northern Rail extension routes and ancillary facilities, Alaska. Report prepared for ICF International. Northern Land Use Research, Inc., Fairbanks.

Potter BA, Bowers PM, Reuther JD, Mason OK. 2007c. Holocene assemblage variability in the Tanana Basin: NLUR archaeological research, 1994-2004. Alaska Journal of Anthropology 5(1):23-42.
Powers WR, Hoffecker JF. 1989. Late Pleistocene settlement in the Nenana Valley, central Alaska. American Antiquity 54(2):263-87.

Powers WR, Maxwell HE. 1986. Lithic remains from Panguingue Creek, an early Holocene site in the northern foothills of the Alaska Range. Studies in History 189. Alaska Historical Commission, Anchorage.

Powers WR, Guthrie RD, Hoffecker JF, editors. 1983. Dry Creek: archeology and paleoecology of a Late Pleistocene Alaskan hunting camp. Report submitted to the National Park Service.

Reger DR. 1985. Archaeological survey of the Tazlina Lake area, 1982-83. Report of Investigations 85-9, Alaska Division of Geological and Geophysical Surveys, Anchorage.

Reger DR, Bacon GH. 1996. Long Lake. In: West FH, editor. American Beginnings: The Prehistory and Palaeoecology of Beringia. Chicago: University of Chicago Press. p 436-7.

Reger RD, Pewe TL, West FH, Skarland I. 1964. Geology and archaeology of the Yardang Field station. Anthropological Papers of the University of Alaska 12(2):92-100.

Reger DR, Cole T, Brown CM. 1975. Report of archaeological and historical investigations along the Copper River, Tasnuna River to Chitina. Miscellaneous Publications, History and Archaeology Series 10. Anchorage: Alaska Office of History and Archaeology.

Reimer PJ, Baillie MGL, Bard E, Bayliss A, Beck JW, Bertrand CJH, Blackwell PG, Buck CE, Burr GS, Cutler KB, Damon PE, Edwards RL, Fairbanks RG, Friedrich M, Guilderson TP, Hogg AG, Hughen KA, Kromer B, McCormac G, Manning S, Bronk Ramsey C, Reimer RW, Remmele S, Southon JR, Stuiver M, Talamo S, Taylor FW, van der Plicht J, Weyhenmeyer CE. 2004. IntCal04 terrestrial radiocarbon age calibration, 0-26 cal kyr BP. Radiocarbon 46(3):1029-58.

Reuther JD, Kriz PJ, Potter BA, Bowers PM. 2003. Cultural resources survey and evaluation of tunnels and proposed stabilization areas along the Alaska railroad, Healy Canyon, Alaska. Prepared for Alaska Railroad Corporation and URS Corporation by Northern Land Use Research, Inc., Fairbanks. NLUR Technical Report No. 202.

Schiffer MB. 1976. Behavioral Archaeology. New York: Academic Press. 222 p.

Shapiro B, Drummond AJ, Rambaut A, Wilson MC, Matheus PE, Sher AV, Pybus OG, Gilbert MTP, Barnes I, Binladen J, Willerslev E, Hansen AJ, Baryshnikov GF, Burns JA, Davydov S, Driver JC, Froese DG, Harington CR, Keddie G, Kosintsev P, Kunz ML, Martin LD, Stephenson RO, Storer J, Tedford R, Zimov S, Cooper A. 2004. Rise and fall of the Beringian steppe bison. Science 306(5701):1561-5.

Sheppard WL, Steffian AF, Staley DP, Bigelow NH. 1991. Late Holocene occupations at the Terrace site, Tok, Alaska. Report prepared for US Air Force, Elec- 
tronic Systems Division. Arctic Environmental Information and Data Center, University of Alaska, Anchorage.

Shinkwin AD. 1977. The "archaeological visibility" of northern Athapaskans in the Tanana River area, central Alaska: a discussion. In: Helmer JW, Van Dyke S, Kense FJ, editors. Problems in the Prehistory of the North American Subarctic: The Athapaskan Question. Calgary: University of Calgary Archaeological Association. p 40-5.

Shinkwin AD. 1979. Dakah De'nin's Village and the Dixthada site: a contribution to northern Alaskan prehistory. National Museum of Man Mercury Series No. 91. Ottowa: National Museum of Man.

Stuiver M, Reimer PJ. 1993. Extended ${ }^{14} \mathrm{C}$ data base and revised CALIB $3.0{ }^{14} \mathrm{C}$ age calibration program. $\mathrm{Ra}$ diocarbon 35(1):215-30.

Surovell TA, Brantingham PJ. 2007. A note on the use of temporal frequency distributions in studies of prehistoric demography. Journal of Archaeological Science 34(11):1868-77.

Thorson RM. 2006. Artifact mixing at the Dry Creek site, interior Alaska. Anthropological Papers of the University of Alaska, New Series 4(1):1-10.

US Bureau of Indian Affairs. 1986. Preliminary site report on the McCurdy archeological site, GUL-100. Report submitted to the State Historic Preservation Officer. On file at the Office of History and Archaeology, Anchorage.

US Geological Survey. 1979. 15-minute digital elevation models. Reston: USGS

VanderHoek R, Dilley TE, Holmes CE. 1997. North Gerstle Point: a deeply stratified multi-component site in the central Tanana Valley, Alaska. Paper presented at the 24th Annual Meeting of the Alaska Anthropological Association, Whitehorse.

Waguespack NM, Surovell TA. 2003. Clovis hunting strategies, or how to make out on plentiful resources. American Antiquity 68(2):333-52.

Ward GK, Wilson SR. 1978. Procedures for comparing and combining radiocarbon age determinations: a critique. Archaeometry 20(1):19-31.

Warhaftig C. 1965. Physiographic divisions of Alaska. Geological Survey Professional Paper 482. Washington, DC: United States Government Printing Office.

West CE. 1978. Archeology of the Birches site, Lake Minchumina, Alaska [MA thesis]. Fairbanks: University of Alaska Fairbanks.

West FH. 1967. The Donnelly Ridge site and the definition of an early core and blade complex in central Alaska. American Antiquity 32(3):360-82.

West FH. 1972. Archaeological and paleoecological research in the Tangle Lakes, central Alaska, 19661972. Manuscript on file at Alaska Methodist Univer- sity, Anchorage.

West FH. 1975. Dating the Denali complex. Arctic Anthropology 12(1):76-81.

West FH. 1981. The Archaeology of Beringia. New York: Columbia Press. 268 p.

West FH, editor. 1996a. American Beginnings: The Prehistory and Palaeoecology of Beringia. Chicago: University of Chicago Press. 600 p.

West FH. 1996b. Beringia and New World origins. II. The archaeological evidence. In: West FH, editor. American Beginnings: The Prehistory and Palaeoecology of Beringia. Chicago: University of Chicago Press. p 537-59.

West FH. 1996c. Teklanika West. In: West FH, editor. American Beginnings: The Prehistory and Palaeoecology of Beringia. Chicago: University of Chicago Press. p 332-43.

West FH, Robinson BS, Curran ML. 1996a. Phipps site. In: West FH, editor. American Beginnings: The Prehistory and Palaeoecology of Beringia. Chicago: University of Chicago Press. p 381-6.

West FH, Robinson BS, West CF. 1996b. Whitmore Ridge. In: West FH, editor. American Beginnings: The Prehistory and Palaeoecology of Beringia. Chicago: University of Chicago Press. p 386-94.

West FH, Robinson BS, Dixon RG. 1996c. Sparks Point. In: West FH, editor. American Beginnings: The Prehistory and Palaeoecology of Beringia. Chicago: University of Chicago Press. p 394-8.

Workman WB. 1976. Archeological investigations at GUL-077: a prehistoric site near Gulkana, Alaska [unpublished report]. Manuscript on file at Alaska Office of History and Archaeology, Anchorage.

Workman WB. 1978. Prehistory of the Aishihik-Kluane Area, Southwest Yukon Territory. National Museum of Man Mercury Series, Archaeological Survey of Canada Paper No. 74. Ottawa: National Museum of Man.

Yesner DR. 1996. Human adaptation at the PleistoceneHolocene boundary (circa 13,000 to 8,000 BP) in eastern Beringia. In: Straus LG, Eriksen BV, Erlandson $\mathrm{JM}$, Yesner DR, editors. Humans at the End of the Ice Age: The Archaeology of the Pleistocene-Holocene Transition. New York: Plenum Press. p 255-76.

Yesner DR. 2001. Human dispersal into interior Alaska: antecedent conditions, mode of colonization, and adaptation. Quaternary Science Reviews 20(1-3):31527.

Yesner DR, Pearson GA. 2002. Microblades and migrations: ethnic and economic models in the peopling of the Americas. In: Elston RG, Kuhn SL, editors. Thinking Small: Global Perspectives on Microlithization. Arlington: Archeological Papers of the American Anthropological Association Number 12. p 133-61. 


\section{APPENDIX}

Table A1 Radiocarbon-dated component date list (see Methods section for details).

\begin{tabular}{|c|c|c|c|c|c|c|}
\hline Component $^{\mathrm{a}}$ & $\begin{array}{l}{ }^{14} \mathrm{C} \text { assay } \\
\text { (BP) }\end{array}$ & Lab \# & Material $^{\mathrm{b}}$ & Context $\mathrm{t}^{\mathrm{c}}$ & $\begin{array}{l}\text { Calib. yr BP } \\
(2-\sigma \text { range })\end{array}$ & Reference \\
\hline \multirow[t]{7}{*}{ Swan Point CZ4 } & $11,660 \pm 70$ & Beta-56667 & $\mathrm{c}$ & stratigraphic & $13,693-13,344$ & \multirow[t]{8}{*}{$\begin{array}{l}\text { Holmes et al. } \\
\text { 1996; Holmes } \\
2004\end{array}$} \\
\hline & $11,660 \pm 60$ & Beta-71372 & $\mathrm{c}$ & stratigraphic & $13,680-13,360$ & \\
\hline & $11,770 \pm 140$ & AA-19322 & o & $\begin{array}{l}\text { organic resi- } \\
\text { due on artifact }\end{array}$ & $13,901-13,320$ & \\
\hline & $12,040 \pm 40$ & unreported & $\mathrm{c}$ & hearth & $14,004-13,788$ & \\
\hline & $12,060 \pm 70$ & CAMS-17045 & iv & ivory collagen & $14,069-13,768$ & \\
\hline & $12,110 \pm 50$ & unreported & o & hearth residue & $14,090-13,823$ & \\
\hline & $12,360 \pm 60$ & unreported & o & hearth residue & $14,748-14,067$ & \\
\hline average & $12,003 \pm 22$ & & & & $13,956-13,775$ & \\
\hline \multirow[t]{2}{*}{ Mead CZ4 } & $11,560 \pm 80$ & CAMS-5198 & $\mathrm{c}$ & stratigraphic & $13,614-13,253$ & \multirow{3}{*}{ Dilley 1998} \\
\hline & $11,600 \pm 60$ & CAMS-4877 & $\mathrm{c}$ & stratigraphic & $13,618-13,302$ & \\
\hline average & $11,587 \pm 48$ & & & & $13,581-13,301$ & \\
\hline \multirow{2}{*}{$\begin{array}{l}\text { Broken Mammoth } \\
\text { CZ4 }\end{array}$} & $11,420 \pm 70$ & CAMS-5358 & $\mathrm{c}$ & hearth & $13,411-13,152$ & \multirow[t]{3}{*}{ Holmes 1996} \\
\hline & $11,510 \pm 120$ & WSU-4262 & $\mathrm{c}$ & hearth & $13,647-13,154$ & \\
\hline average & $11,443 \pm 60$ & & & & $13,415-13,195$ & \\
\hline Owl Ridge C1 & $11,340 \pm 150$ & Beta-11209 & $\mathrm{c}$ & stratigraphic & $13,483-12,919$ & Phippen 1988 \\
\hline \multirow[t]{4}{*}{ Little Delta Dune C1 } & $11,300 \pm 40$ & Beta-232394 & $\mathrm{c}$ & hearth -split & $13,262-13,105$ & \multirow[t]{4}{*}{ Potter et al. 2007b } \\
\hline & $11,250 \pm 60$ & AA-76863 & $\mathrm{c}$ & hearth -split & $13,263-13,020$ & \\
\hline & $11,420 \pm 60$ & Beta-233316 & $\mathrm{c}$ & hearth & $13,401-13,173$ & \\
\hline & $11,320 \pm 30$ & & & & $13,269-13,124$ & \\
\hline \multirow[t]{3}{*}{ Walker Road C1 } & $11,010 \pm 230$ & AA-1683 & $\mathrm{c}$ & hearth & $13,377-12,397$ & \multirow[t]{4}{*}{ Goebel et al. 1996} \\
\hline & $11,170 \pm 180$ & AA-1681 & $\mathrm{c}$ & hearth & $13,363-12,834$ & \\
\hline & $11,300 \pm 120$ & AA-2264 & $\mathrm{c}$ & hearth & $13,379-12,948$ & \\
\hline average & $11,220 \pm 92$ & & & & $13,263-12,938$ & \\
\hline Moose Creek C1 & $11,190 \pm 60$ & Beta-96627 & $\mathrm{c}$ & hearth & $13,209-12,952$ & Pearson 1999 \\
\hline Dry Creek C1 & $11,120 \pm 85$ & SI-2880 & $\mathrm{c}$ & stratigraphic & $13,183-12,893$ & Powers et al. 1983 \\
\hline Moose Creek C2 & $10,500 \pm 60$ & Beta-106040 & $\mathrm{c}$ & hearth & $12,714-12,160$ & Pearson 1999 \\
\hline \multirow[t]{4}{*}{ Mead CZ3 } & $10,410 \pm 80$ & CAMS-5197 & $\mathrm{c}$ & stratigraphic & $12,652-12,045$ & \multirow[t]{4}{*}{ Dilley 1998} \\
\hline & $10,460 \pm 110$ & CAMS-4876 & $\mathrm{c}$ & stratigraphic & $12,769-12,045$ & \\
\hline & $10,760 \pm 170$ & WSU-4425 & $\mathrm{c}$ & stratigraphic & $13,069-12,175$ & \\
\hline & $10,469 \pm 60$ & & & & $12,671-12,142$ & \\
\hline $\begin{array}{l}\text { Broken Mammoth } \\
\text { CZ3 }\end{array}$ & $10,290 \pm 70$ & CAMS-5357 & $\mathrm{c}$ & hearth & $12,386-11,769$ & Holmes 1996 \\
\hline Phipps site & $10,230 \pm 70$ & Beta-63672 & $\mathrm{c}$ & stratigraphic & $12,350-11,624$ & West et al. 1996a \\
\hline \multirow{4}{*}{ Swan Point CZ3 } & $10,010 \pm 90$ & Beta-190578 & $\mathrm{c}$ & hearth & $11,956-11,242$ & \multirow[t]{4}{*}{ Holmes et al. 1996} \\
\hline & $10,025 \pm 60$ & Beta-170458 & $\mathrm{c}$ & hearth & $11,805-11,268$ & \\
\hline & $10,230 \pm 80$ & Beta-56666 & $\mathrm{c}$ & hearth & $12,366-11,616$ & \\
\hline & $10,079 \pm 42$ & & & & $11,957-11,396$ & \\
\hline XBD-308 & $10,050 \pm 70$ & Beta-219659 & $\mathrm{c}$ & stratigraphic & $11,958-11,286$ & Potter et al. 2007a \\
\hline XBD-338 C2 & $10,000 \pm 80$ & Beta-232397 & $\mathrm{c}$ & stratigraphic & $11,819-11,240$ & Potter et al. $2007 \mathrm{~b}$ \\
\hline \multirow[t]{5}{*}{ Whitmore Ridge C1 } & $9600 \pm 140$ & Beta- 64578 & so & stratigraphic & $11,249-10,525$ & \multirow[t]{5}{*}{ West et al. 1996b } \\
\hline & $9830 \pm 60$ & Beta-70240 & so & stratigraphic & $11,394-11,161$ & \\
\hline & $9890 \pm 70$ & Beta-62222 & so & stratigraphic & $11,609-11,194$ & \\
\hline & $10,270 \pm 70$ & Beta-77268 & so & stratigraphic & $12,377-11,761$ & \\
\hline & $9953 \pm 37$ & & & & $11,603-11,249$ & \\
\hline Little Delta River \#3 & $9920 \pm 60$ & Beta-12331 & $\mathrm{c}$ & stratigr & $11,610-11,216$ & \multirow{3}{*}{$\begin{array}{l}\text { Higgs et al. } 1999 \\
\text { Powers and Max- } \\
\text { well } 1986\end{array}$} \\
\hline \multirow[t]{2}{*}{$\begin{array}{l}\text { Panguingue Creek } \\
\mathrm{C} 1\end{array}$} & $10,180 \pm 130$ & AA-1686 & $\mathrm{c}$ & stratigraphic & $12,379-11,318$ & \\
\hline & $9836 \pm 62$ & Gx-17457 & $\mathrm{c}$ & stratigraphic & $11,401-11,140$ & \\
\hline
\end{tabular}


Table A1 Radiocarbon-dated component date list (see Methods section for details). (Continued)

\begin{tabular}{|c|c|c|c|c|c|c|}
\hline Component ${ }^{\mathrm{a}}$ & $\begin{array}{l}{ }^{14} \mathrm{C} \text { assay } \\
\text { (BP) }\end{array}$ & Lab \# & Material $^{\mathrm{b}}$ & Context ${ }^{\mathrm{c}}$ & $\begin{array}{l}\text { Calib. yr BP } \\
(2-\sigma \text { range })\end{array}$ & Reference \\
\hline average & $\begin{array}{l}9850 \pm 140 \\
9893 \pm 52\end{array}$ & Beta-55101 & $\mathrm{c}$ & stratigraphic & $\begin{array}{l}11,818-10,777 \\
11,599-11,202\end{array}$ & \\
\hline Gerstle River C1 & $9740 \pm 50$ & Beta-133751 & $\mathrm{c}$ & stratigraphic & $11,247-10,883$ & Potter 2005 \\
\hline Little Delta Dune C2 & $9670 \pm 40$ & Beta-232393 & $\mathrm{c}$ & stratigraphic & $11,203-10,796$ & Potter et al. 2007b \\
\hline \multirow[t]{9}{*}{ Dry Creek C2 } & $7895 \pm 105$ & SI-2328 & $\mathrm{c}$ & stratigraphic & $9009-8459$ & $\begin{array}{l}\text { Powers et al. } \\
\text { 1983; Bigelow } \\
\text { and Powers } 1994\end{array}$ \\
\hline & $8915 \pm 70$ & AA-11730 & $\mathrm{c}$ & stratigraphic & $10,233-9776$ & \\
\hline & $9340 \pm 195$ & SI-2329 & $\mathrm{c}$ & stratigraphic & $11,186-10,178$ & \\
\hline & $9340 \pm 95$ & SI-11733 & $\mathrm{c}$ & stratigraphic & $11,056-10,248$ & \\
\hline & $9690 \pm 75$ & AA-11732 & $\mathrm{c}$ & stratigraphic & $11,236-10,778$ & \\
\hline & $10,060 \pm 85$ & AA-11727 & $\mathrm{c}$ & stratigraphic & $11,971-11,273$ & \\
\hline & $10,540 \pm 70$ & AA-11731 & $\mathrm{c}$ & stratigraphic & $12,792-12,238$ & \\
\hline & $10,615 \pm 100$ & AA-11728 & $\mathrm{c}$ & stratigraphic & $12,845-12,239$ & \\
\hline & $10,690 \pm 250$ & SI-1561 & $\mathrm{c}$ & hearth & $13,116-11,822$ & \\
\hline average & $9657 \pm 31$ & & & & $11,191-10,801$ & \\
\hline Little Delta Dune C3 & $9650 \pm 60$ & Beta-220218 & $\mathrm{c}$ & hearth & $11,200-10,775$ & Potter et al. 2007b \\
\hline \multirow[t]{2}{*}{ Gerstle River C2 } & $9400 \pm 50$ & Beta-183110 & $\mathrm{c}$ & hearth & $11,057-10,571$ & Potter 2005 \\
\hline & $9510 \pm 40$ & Beta-134098 & $\mathrm{c}$ & hearth & $11,075-10,609$ & \\
\hline average & $9449 \pm 41$ & & & & $11,057-10,571$ & \\
\hline XBD-303 & $9340 \pm 80$ & Beta-219658 & $\mathrm{c}$ & stratigraphic & $10,740-10,281$ & Potter et al. 2007a \\
\hline XBD-312 & $9290 \pm 50$ & Beta-220214 & $\mathrm{c}$ & stratigraphic & $10,647-10,285$ & Potter et al. 2007a \\
\hline \multirow[t]{3}{*}{ Sparks Point } & $9060 \pm 425$ & UGa-941 & so & stratigraphic & $11,335-9033$ & West et al. 1996c \\
\hline & $9110 \pm 80$ & Beta-64577 & so & stratigraphic & $10,515-9967$ & \\
\hline & $9200 \pm 60$ & Beta-62773 & so? & stratigraphic & $10,514-10,237$ & \\
\hline average & $9166 \pm 47$ & & & & $10,486-10,233$ & \\
\hline \multirow{9}{*}{$\begin{array}{l}\text { Healy Lake Village } \\
\text { Chindadn (levels } \\
6-10)\end{array}$} & $8655 \pm 280$ & Gx-2171 & so? & stratigraphic & $10,406-9010$ & Cook 1996 \\
\hline & $8680 \pm 240$ & Gx-2170 & $\mathrm{c}$ & stratigraphic & $10,287-9092$ & \\
\hline & $8990 \pm 60$ & Beta-76070 & $\mathrm{c}$ & stratigraphic & $10,245-9916$ & \\
\hline & $9245 \pm 213$ & AU-1 & $\mathrm{c}$ & hearth & $11,162-9892$ & \\
\hline & $9895 \pm 210$ & Gx-2174 & $\mathrm{c}$ & hearth & $12,111-10,703$ & \\
\hline & $10,040 \pm 210$ & SI-739 & $\mathrm{c}$ & stratigraphic & $12,567-10,874$ & \\
\hline & $10,434 \pm 279$ & AU-3 & $\mathrm{c}$ & stratigraphic & $12,869-11,342$ & \\
\hline & $10,500 \pm 280$ & Gx-1944 & $\mathrm{c}$ & stratigraphic & $12,925-11,394$ & \\
\hline & $9142 \pm 51$ & & & & $10,485-10,221$ & \\
\hline \multirow[t]{2}{*}{ Chugwater C2 } & $9460 \pm 130$ & Beta-19498 & $\mathrm{c} ?$ & stratigraphic? & $11,176-10,304$ & $\begin{array}{l}\text { Maitland 1986; } \\
\text { Lively } 1996\end{array}$ \\
\hline & $8960 \pm 130$ & Beta-18509 & $\mathrm{c} ?$ & stratigraphic? & $10,403-9631$ & \\
\hline average & $9075 \pm 92$ & & & & 10,500-9918 & \\
\hline \multirow[t]{10}{*}{ Gerstle River C3 } & $8820 \pm 50$ & Beta-183109 & $\mathrm{c}$ & hearth & $10,156-9686$ & Potter 2001, 2005 \\
\hline & $8830 \pm 50$ & Beta-181678 & $\mathrm{c}$ & hearth & $10,156-9698$ & \\
\hline & $8860 \pm 70$ & Beta- 133750 & $\mathrm{c}$ & hearth & $10,184-9700$ & \\
\hline & $8890 \pm 40$ & Beta-167397 & $\mathrm{c}$ & hearth & $10,187-9798$ & \\
\hline & $8900 \pm 40$ & Beta-181679 & $\mathrm{c}$ & hearth & $10,190-9896$ & \\
\hline & $8910 \pm 40$ & Beta-167399 & $\mathrm{c}$ & hearth & $10,188-9908$ & \\
\hline & $8950 \pm 40$ & Beta-167395 & $\mathrm{c}$ & hearth & $10,221-9917$ & \\
\hline & $9030 \pm 70$ & AA-51254 & $\mathrm{c}$ & hearth & $10,374-9913$ & \\
\hline & $9080 \pm 50$ & Beta-183108 & $\mathrm{c}$ & hearth & $10,386-10,176$ & \\
\hline & $8882 \pm 17$ & & & & $10,156-9911$ & \\
\hline Little Delta Dune C4 & $8880 \pm 40$ & Beta-232392 & $\mathrm{c}$ & stratigraphic & 10,179-9789 & Potter et al. 2007b \\
\hline XBD-306 & $8930 \pm 90$ & Beta-220216 & c & stratigraphic & $10,238-9710$ & Potter et al. 2007a \\
\hline Erodeaway & $8640 \pm 170$ & WSU-3683 & $\mathrm{c}$ & hearth & $10,184-9305$ & Holmes 1988 \\
\hline Gerstle River C4 & $8660 \pm 40$ & Beta-167396 & $\mathrm{c}$ & hearth & $9697-9539$ & Potter 2005 \\
\hline Carlo Creek C1 & $8400 \pm 200$ & WSU-1700 & $\mathrm{c}$ & hearth & $9910-8774$ & Bowers 1980 \\
\hline
\end{tabular}


Table A1 Radiocarbon-dated component date list (see Methods section for details). (Continued)

\begin{tabular}{|c|c|c|c|c|c|c|}
\hline Component $^{\mathrm{a}}$ & $\begin{array}{l}{ }^{14} \mathrm{C} \text { assay } \\
(\mathrm{BP})\end{array}$ & Lab \# & Material $^{\mathrm{b}}$ & Context ${ }^{c}$ & $\begin{array}{l}\text { Calib. yr BP } \\
(2-\sigma \text { range })\end{array}$ & Reference \\
\hline & $8690 \pm 330$ & Gx-5132 & $\mathrm{c}$ & hearth & $10,650-8793$ & \\
\hline average & $8478 \pm 171$ & & & & $10,113-9012$ & \\
\hline \multirow[t]{2}{*}{ Gerstle River C5 } & $7600 \pm 140$ & WSU-4888 & $\mathrm{c}$ & $\begin{array}{l}\text { stratigraphic } \\
\text { (ULD) }\end{array}$ & $8716-8047$ & Potter 2005 \\
\hline & $8280 \pm 60$ & Beta-98434 & $\mathrm{c}$ & $\begin{array}{l}\text { stratigraphic } \\
\text { (LLD) }\end{array}$ & $9442-9037$ & \\
\hline average & $8174 \pm 55$ & & & & 9283-9008 & \\
\hline XBD-307 & $8070 \pm 60$ & Beta-220217 & $\mathrm{c}$ & stratigraphic & $9240-8720$ & Potter et al. 2007a \\
\hline XBD-340 & $8000 \pm 50$ & Beta-232399 & $\mathrm{c}$ & stratigraphic & $9011-8652$ & Potter et al. 2007b \\
\hline XBD-289 & $7960 \pm 70$ & Beta-219649 & $\mathrm{c}$ & stratigraphic & $9004-8610$ & Potter et al. 2007a \\
\hline Houdini Creek & $7880 \pm 60$ & Beta-74737 & $\mathrm{c}$ & stratigraphic & $8978-8552$ & Bowers et al. 1995 \\
\hline \multirow[t]{6}{*}{$\begin{array}{l}\text { Panguingue Creek } \\
\mathrm{C} 2\end{array}$} & $8600 \pm 200$ & AA-1689 & $\mathrm{c}$ & stratigraphic & $10,189-9137$ & $\begin{array}{l}\text { Powers and Max- } \\
\text { well } 1986\end{array}$ \\
\hline & $7595 \pm 405$ & Gx-13012 & $\mathrm{c}$ & stratigraphic & $9405-7676$ & \\
\hline & $7430 \pm 270$ & AA- 1688 & $\mathrm{c}$ & stratigraphic & $8971-7691$ & \\
\hline & $7130 \pm 180$ & Beta-15094 & $\mathrm{c}$ & stratigraphic & $8326-7623$ & \\
\hline & $7850 \pm 180$ & Beta-15093 & $\mathrm{c}$ & stratigraphic & $9242-8330$ & \\
\hline & $7749 \pm 97$ & & & & $8970-8371$ & \\
\hline Lucky Strike site & $7760 \pm 50$ & Beta-196499 & $\mathrm{c}$ & stratigraphic & $8627-8425$ & Reuther et al. 2003 \\
\hline XBD-326 & $7740 \pm 60$ & Beta-219663 & $\mathrm{c}$ & stratigraphic & $8627-8410$ & Potter et al. 2007a \\
\hline \multirow{3}{*}{$\begin{array}{l}\text { Broken Mammoth } \\
\text { CZ2 }\end{array}$} & $7200 \pm 205$ & UGa-6281D & $\mathrm{c}$ & hearth -split & $8401-7659$ & Holmes 1996 \\
\hline & $7600 \pm 160$ & WSU-4264 & $\mathrm{c}$ & hearth -split & $8850-8023$ & \\
\hline & $7700 \pm 80$ & WSU-4508 & $\mathrm{c}$ & hearth & $8633-8372$ & \\
\hline average & $7628 \pm 78$ & & & & $8592-8222$ & \\
\hline \multirow[t]{3}{*}{ Owl Ridge C2 } & $7230 \pm 100$ & Beta-11437 & $\mathrm{c}$ & stratigraphic & $8305-7850$ & Phippen 1988 \\
\hline & $7660 \pm 100$ & Beta-11436 & $\mathrm{c}$ & stratigraphic & $8643-8206$ & \\
\hline & $8130 \pm 140$ & Beta-5418 & $\mathrm{c}$ & stratigraphic & $9426-8645$ & \\
\hline average & $7584 \pm 63$ & & & & $8539-8213$ & \\
\hline Swan Point CZ2 & $7400 \pm 80$ & WSU-4426 & $\mathrm{c}$ & stratigraphic & $8372-8039$ & Holmes et al. 1996 \\
\hline XBD-325 & $7360 \pm 40$ & Beta-220682 & $\mathrm{c}$ & stratigraphic & $8312-8040$ & Potter et al. 2007a \\
\hline XBD-291 & $7350 \pm 60$ & Beta-219650 & $\mathrm{c}$ & stratigraphic & $8318-8024$ & Potter et al. 2007a \\
\hline \multirow[t]{2}{*}{ Jay Creek Ridge C1 } & $6970 \pm 210$ & Beta-7304 & $\mathrm{c}$ & stratigraphic & $8187-7435$ & Dixon et al. 1985 \\
\hline & $7240 \pm 110$ & Beta-7306 & $\mathrm{c}$ & stratigraphic & $8321-7853$ & \\
\hline average & $7182 \pm 97$ & & & & 8189-7794 & \\
\hline Teklanika West C1 & $7130 \pm 98$ & Gx-18518 & $\mathrm{c}$ & stratigraphic & $8170-7754$ & West 1996a \\
\hline \multirow[t]{2}{*}{ Owl Ridge C3 } & $6900 \pm 265$ & D-3070 & $\mathrm{c}$ & stratigraphic & $8302-7272$ & Phippen 1988 \\
\hline & $7035 \pm 380$ & Gx-13009 & $\mathrm{c}$ & stratigraphic & $8642-7029$ & \\
\hline average & $6944 \pm 217$ & & & & $8195-7424$ & \\
\hline Campus Area J6 & $6850 \pm 70$ & Beta-97212 & $\mathrm{c}$ & stratigraphic & $7833-7579$ & $\begin{array}{l}\text { Pearson and Pow- } \\
\text { ers } 2001\end{array}$ \\
\hline XBD-313 & $6750 \pm 60$ & Beta-219651 & $\mathrm{c}$ & hearth & 7691-7504 & Potter et al. 2007a \\
\hline Long Lake & $6606 \pm 115$ & UGa-949 & $\mathrm{c}$ & stratigraphic & $7672-7293$ & $\begin{array}{l}\text { Reger and Bacon } \\
1996\end{array}$ \\
\hline XBD-311 & $6490 \pm 50$ & Beta-220215 & $\mathrm{c}$ & stratigraphic & 7490-7289 & Potter et al. 2007a \\
\hline Mead CZ2 & $6070 \pm 170$ & & $\mathrm{c}$ & stratigraphic & $7316-6505$ & Dilley 1998 \\
\hline XBD-288 & $6060 \pm 60$ & Beta-219654 & $\mathrm{c}$ & stratigraphic & $7156-6749$ & Potter et al. 2007a \\
\hline XBD-282 & $5920 \pm 50$ & Beta-221332 & $\mathrm{c}$ & stratigraphic & $6882-6644$ & Potter et al. 2007a \\
\hline \multirow[t]{2}{*}{ Gerstle River C6 } & $5050 \pm 90$ & N-4958 & $\mathrm{c}$ & $\begin{array}{l}\text { stratigraphic } \\
\text { (ULD) }\end{array}$ & $5984-5603$ & Potter 2005 \\
\hline & $6220 \pm 80$ & WSU-4892 & $\mathrm{c}$ & $\begin{array}{l}\text { stratigraphic } \\
\text { (LLD) }\end{array}$ & $7308-6912$ & \\
\hline average & $5704 \pm 60$ & & & & $6656-6324$ & \\
\hline Moose Creek C3 & $5680 \pm 50$ & Beta-106041 & $\mathrm{c}$ & stratigraphic & $6631-6321$ & Pearson 1999 \\
\hline XBD-317 & $5610 \pm 50$ & Beta-219653 & $\mathrm{c}$ & stratigraphic & $6485-6301$ & Potter et al. 2007a \\
\hline XBD-335 C1 & $5400 \pm 40$ & Beta-232391 & $\mathrm{c}$ & stratigraphic & $6292-6020$ & Potter et al. 2007b \\
\hline
\end{tabular}


Table A1 Radiocarbon-dated component date list (see Methods section for details). (Continued)

\begin{tabular}{|c|c|c|c|c|c|c|}
\hline Component $^{\mathrm{a}}$ & $\begin{array}{l}{ }^{14} \mathrm{C} \text { assay } \\
\text { (BP) }\end{array}$ & Lab \# & Material $^{b}$ & Context $\mathrm{t}^{\mathrm{c}}$ & $\begin{array}{l}\text { Calib. yr BP } \\
(2-\sigma \text { range })\end{array}$ & Reference \\
\hline Flat Knoll C1 & $5230 \pm 140$ & Beta-7695 & $\mathrm{c}$ & stratigraphic & $6290-5663$ & Dixon et al. 1985 \\
\hline XBD-328 & $5170 \pm 50$ & Beta-219664 & $\mathrm{c}$ & stratigraphic & $6171-5750$ & Potter et al. 2007a \\
\hline \multirow[t]{2}{*}{ Whitmore Ridge C2 } & $5080 \pm 130$ & $\mathrm{I}-4231$ & $\mathrm{c} ?$ & stratigraphic & $6179-5588$ & West et al. 1996b \\
\hline & $5480 \pm 300$ & UGa-530 & so & stratigraphic & $6942-5603$ & \\
\hline average & $5143 \pm 119$ & & & & $6189-5616$ & \\
\hline Butte Lake C2 & $5030 \pm 200$ & Beta-10751 & $\mathrm{c}$ & Feature 11 & $6270-5323$ & Betts 1987 \\
\hline XBD-283 & $5000 \pm 50$ & Beta-219660 & $\mathrm{c}$ & stratigraphic & $5893-5615$ & Potter et al. 2007a \\
\hline XBD-342 & $4670 \pm 40$ & Beta-232395 & $\mathrm{c}$ & stratigraphic & $5575-5312$ & Potter et al. $2007 \mathrm{~b}$ \\
\hline Swan Point CZ1B & $4620 \pm 40$ & unreported & $\mathrm{u}$ & unreported & $5469-5087$ & Holmes 2004 \\
\hline \multirow{5}{*}{$\begin{array}{l}\text { Broken Mammoth } \\
\text { CZ1B }\end{array}$} & $4525 \pm 90$ & WSU-4458 & $\mathrm{c}$ & hearth -split & $5454-4873$ & Holmes 1996 \\
\hline & $4540 \pm 90$ & WSU-4456 & $\mathrm{c}$ & hearth -split & $5466-4881$ & \\
\hline & $4545 \pm 90$ & WSU-4457 & $\mathrm{c}$ & hearth & $5467-4833$ & \\
\hline & $4690 \pm 110$ & WSU-4350 & $\mathrm{c}$ & hearth & $5642-5048$ & \\
\hline & $4565 \pm 47$ & & & & $5446-5047$ & \\
\hline XBD-287 & $4490 \pm 50$ & Beta-219648 & $\mathrm{c}$ & stratigraphic & $5307-4973$ & Potter et al. 2007a \\
\hline $\begin{array}{l}\text { Panguingue Creek } \\
\text { C3 }\end{array}$ & $4510 \pm 95$ & Gx-13011 & $\mathrm{c}$ & stratigraphic & $5448-4867$ & $\begin{array}{l}\text { Powers and Max- } \\
\text { well } 1986\end{array}$ \\
\hline Mount Hayes 35 & $4450 \pm 140$ & unreported & $\mathrm{u}$ & $\begin{array}{l}\text { associated with } \\
\text { "dwelling"? }\end{array}$ & $5573-4654$ & Mobley 1982 \\
\hline Landmark Gap Trail & $4330 \pm 135$ & Beta-1726 & $\mathrm{c}$ & stratigraphic & $5309-4533$ & Mobley 1982 \\
\hline XBD-301 & $4360 \pm 50$ & Beta-219657 & $\mathrm{c}$ & stratigraphic & $5255-4836$ & Potter et al. 2007a \\
\hline $\begin{array}{l}\text { North Gerstle Point } \\
\text { C2 }\end{array}$ & $4290 \pm 285$ & unreported & $\mathrm{c}$ & hearth & 5589-4092 & $\begin{array}{l}\text { VanderHoek et al. } \\
1997\end{array}$ \\
\hline \multirow{4}{*}{$\begin{array}{l}\text { Jay Creek Mineral } \\
\text { Lick C1 }\end{array}$} & $4100 \pm 60$ & Beta-5464 & $\mathrm{c}$ & stratigraphic & $4825-4440$ & Dixon et al. 1985 \\
\hline & $4440 \pm 120$ & Beta-7698 & $\mathrm{c}$ & stratigraphic & $5462-4729$ & \\
\hline & $4250 \pm 110$ & Beta-7697 & $\mathrm{c}$ & stratigraphic & $5270-4443$ & \\
\hline & $4184 \pm 48$ & & & & $4844-4574$ & \\
\hline \multirow{2}{*}{ Borrow $\mathrm{C}$ site $\mathrm{C} 1$} & $4020 \pm 65$ & DIC-2283 & $\mathrm{c}$ & stratigraphic & $4810-4294$ & Dixon et al. 1985 \\
\hline & $4570 \pm 100$ & Beta-7844 & $\mathrm{c}$ & stratigraphic & $5531-4890$ & \\
\hline average & $4183 \pm 54$ & & & & $4847-4539$ & \\
\hline XBD-343 & $4160 \pm 40$ & Beta-232396 & $\mathrm{c}$ & stratigraphic & $4831-4571$ & Potter et al. 2007b \\
\hline \multirow[t]{3}{*}{ Tok Terrace $\mathrm{C} 1$} & $4160 \pm 100$ & Beta-40724 & $\mathrm{c}$ & stratigraphic & 4952-4419 & $\begin{array}{l}\text { Sheppard et al. } \\
1991\end{array}$ \\
\hline & $4020 \pm 90$ & Beta-40717 & $\mathrm{c}$ & stratigraphic & $4821-4248$ & \\
\hline & $4083 \pm 67$ & & & & $4821-4427$ & \\
\hline ХMH-166 & $4100 \pm 270$ & $\mathrm{I}-4592$ & & unreported & $5434-3866$ & West 1972 \\
\hline XBD-316 & $4050 \pm 50$ & Beta-219652 & $\mathrm{c}$ & stratigraphic & $4807-4418$ & Potter et al. 2007a \\
\hline TLM-207 C1 & $4030 \pm 220$ & Beta-9897 & c & stratigraphic & $5261-3871$ & Dixon et al. 1985 \\
\hline $\begin{array}{l}\text { Delta River Over- } \\
\text { look C3 }\end{array}$ & $3980 \pm 150$ & Gx-6752 & $\mathrm{c}$ & stratigraphic & $4840-3997$ & $\begin{array}{l}\text { Bacon and } \\
\text { Holmes } 1980\end{array}$ \\
\hline Flat Knoll C2 & $3920 \pm 100$ & Beta-7842 & $\mathrm{c}$ & stratigraphic & $4797-4000$ & Dixon et al. 1985 \\
\hline Rock Creek East & $3866 \pm 47$ & Gx-17392 & $\mathrm{c}$ & unreported & $4416-4154$ & McKay 1981 \\
\hline Gerstle River C7 & $3800 \pm 70$ & $\mathrm{~N}-4959$ & $\mathrm{c}$ & stratigraphic & $4413-3986$ & Potter 2005 \\
\hline \multirow[t]{4}{*}{ Dry Creek C4 } & $3430 \pm 75$ & SI-2332 & $\mathrm{c}$ & stratigraphic & $3871-3480$ & Powers et al. 1983 \\
\hline & $3655 \pm 60$ & SI-1934 & c & stratigraphic & $4149-3835$ & \\
\hline & $4670 \pm 95$ & SI-1937 & $\mathrm{c}$ & stratigraphic & $5595-5053$ & \\
\hline & $3783 \pm 42$ & & & & $4346-3989$ & \\
\hline Little Delta River \#4 & $3700 \pm 70$ & Beta-123332 & $\mathrm{c}$ & stratigraphic & $4239-3848$ & Higgs et al. 1999 \\
\hline XBD-297 & $3620 \pm 50$ & Beta-219661 & $\mathrm{c}$ & stratigraphic & $4088-3777$ & Potter et al. 2007a \\
\hline TLM-169 C1 & $3410 \pm 80$ & Beta-10794 & $\mathrm{c}$ & stratigraphic & $3860-3467$ & Dixon et al. 1985 \\
\hline \multirow[t]{3}{*}{ North Arrow site } & $3220 \pm 90$ & Beta-7299 & $\mathrm{c}$ & stratigraphic & $3684-3245$ & Dixon et al. 1985 \\
\hline & $3675 \pm 160$ & Gx-5630 & $\mathrm{c}$ & hearth? & $4495-3586$ & \\
\hline & $3329 \pm 78$ & & & & $3819-3384$ & \\
\hline
\end{tabular}


Table A1 Radiocarbon-dated component date list (see Methods section for details). (Continued)

\begin{tabular}{|c|c|c|c|c|c|c|}
\hline Component $^{\mathrm{a}}$ & $\begin{array}{l}{ }^{14} \mathrm{C} \text { assay } \\
(\mathrm{BP})\end{array}$ & Lab \# & Material $^{\mathrm{b}}$ & Context ${ }^{c}$ & $\begin{array}{l}\text { Calib. yr BP } \\
(2-\sigma \text { range })\end{array}$ & Reference \\
\hline \multirow[t]{4}{*}{ Fog Creek C1 } & $3160 \pm 70$ & Beta-7687 & $\mathrm{c}$ & stratigraphic & $3557-3215$ & Dixon et al. 1985 \\
\hline & $3180 \pm 170$ & Beta-7685 & $\mathrm{c}$ & stratigraphic & $3829-2957$ & \\
\hline & $3270 \pm 90$ & Beta-7300 & $\mathrm{c}$ & stratigraphic & $3716-3271$ & \\
\hline & $3290 \pm 60$ & Beta-7302 & $\mathrm{c}$ & stratigraphic & $3679-3387$ & \\
\hline average & $3239 \pm 40$ & & & & $3559-3382$ & \\
\hline Tuff Creek North C2 & $3210 \pm 80$ & DIC-2286 & $\mathrm{c}$ & stratigraphic & $3632-3262$ & Dixon et al. 1985 \\
\hline Usibelli & $3195 \pm 295$ & Gx-13013 & $\mathrm{c}$ & stratigraphic & $4228-2739$ & Hoffecker 1985 \\
\hline \multirow{2}{*}{$\begin{array}{l}\text { Healy Lake Village } \\
\text { Levels 4-5 }\end{array}$} & $4010 \pm 110$ & Gx-2163 & $\mathrm{c}$ & stratigraphic & $4827-4159$ & Cook 1996 \\
\hline & $\begin{array}{l}3020 \pm 50 \\
3190 \pm 32\end{array}$ & Beta-76063 & $\mathrm{c}$ & stratigraphic & $\begin{array}{l}3358-3074 \\
3465-3362\end{array}$ & \\
\hline XBD-336 & $3040 \pm 40$ & Beta-232398 & $\mathrm{c}$ & stratigraphic & $3362-3082$ & Potter et al. 2007b \\
\hline \multirow{2}{*}{$\begin{array}{l}\text { Fish Creek concB1, } \\
\text { C2 }\end{array}$} & $3005 \pm 135$ & Gx-4110 & $\mathrm{c}$ & stratigraphic & $3476-2808$ & Cook et al. 1977 \\
\hline & $3065 \pm 115$ & Gx-4109 & $\mathrm{c}$ & stratigraphic & $3555-2947$ & \\
\hline average & $3040 \pm 88$ & & & & 3442 & \\
\hline \multirow[t]{3}{*}{ Campus (Mobley) } & $2725 \pm 125$ & Beta-7075 & $\mathrm{c}$ & stratigraphic & $3240-2488$ & Mobley 1991 \\
\hline & $2860 \pm 180$ & Beta-4260 & $\mathrm{c}$ & stratigraphic & $3450-2500$ & \\
\hline & $3500 \pm 140$ & Beta- 6829 & $\mathrm{c}$ & stratigraphic & $4151-3444$ & \\
\hline average & $3025 \pm 83$ & & & & $3392-2968$ & \\
\hline Owl Knoll & $3010 \pm 110$ & Beta- 123340 & $\mathrm{c}$ & hearth & $3443-2886$ & $\begin{array}{l}\text { Potter et al. 2007c; } \\
\text { Higgs et al. } 1999\end{array}$ \\
\hline \multirow{5}{*}{$\begin{array}{l}\text { Healy Lake Village } \\
\text { Levels 2-3 }\end{array}$} & $2875 \pm 140$ & Gx-2169 & $\mathrm{c}$ & stratigraphic & $3357-2753$ & Cook 1996 \\
\hline & $3580 \pm 140$ & Gx-2165 & $\mathrm{c}$ & stratigraphic & $4286-3484$ & \\
\hline & $3655 \pm 426$ & AU-4 & $\mathrm{c}$ & stratigraphic & $5270-2899$ & \\
\hline & $2660 \pm 100$ & Gx-2176 & $\mathrm{c}$ & stratigraphic & $3003-2367$ & \\
\hline & $2965 \pm 69$ & & & & $3342-2952$ & \\
\hline TLM-096 & $2750 \pm 215$ & DIC-2285 & $\mathrm{c}$ & stratigraphic & $3373-2350$ & Dixon et al. 1985 \\
\hline XBD-281 & $2760 \pm 40$ & Beta-221333 & $\mathrm{c}$ & stratigraphic & $2951-2774$ & Potter et al. 2007a \\
\hline $\begin{array}{l}\text { Rainbow Lake Loc. } \\
1\end{array}$ & $2090 \pm 130$ & Gx-6009 & $\mathrm{c}$ & stratigraphic & $2349-1740$ & $\begin{array}{l}\text { Bacon and } \\
\text { Holmes } 1980\end{array}$ \\
\hline Red's Ravine & $\begin{array}{l}2550 \pm 114 \\
2485 \pm 75\end{array}$ & $\begin{array}{l}\text { Beta-33300/ } \\
\text { ETH-5901 }\end{array}$ & $\mathrm{c}$ & stratigraphic & $\begin{array}{l}2855-2349 \\
2733-2361\end{array}$ & \\
\hline $\begin{array}{l}\text { McCurdy archaeo- } \\
\text { logical site }\end{array}$ & $2410 \pm 100$ & Beta- 14508 & $\mathrm{c}$ & hearth & $2744-2183$ & $\begin{array}{l}\text { US Bureau of In- } \\
\text { dian Affairs } 1986\end{array}$ \\
\hline Dixthada C1 & $2420 \pm 60$ & P-1834 & $\mathrm{c}$ & stratigraphic & $2706-2346$ & Shinkwin 1979 \\
\hline Windy Knoll site & $2340 \pm 145$ & DIC-1903 & $\mathrm{c}$ & hearth & $2745-2011$ & Dixon et al. 1985 \\
\hline $\begin{array}{l}\text { Yardang Flint Sta- } \\
\text { tion C1 }\end{array}$ & $2300 \pm 180$ & $\mathrm{I}-647$ & $\mathrm{c}$ & stratigraphic & 2751-1901 & Reger et al. 1964 \\
\hline \multirow{2}{*}{$\begin{array}{l}\text { Lake Minchumina } \\
\text { C1 (Levels } 4 / 5 \text {, } \\
\text { Blueberry phase) }\end{array}$} & $1950 \pm 320$ & Gx-7116 & $\mathrm{c}$ & stratigraphic & $2716-1293$ & Holmes 1986 \\
\hline & $\begin{array}{l}2365 \pm 140 \\
2298+128\end{array}$ & UGa-634 & $\mathrm{c}$ & hearth & $\begin{array}{l}2752-2062 \\
2713-2005\end{array}$ & \\
\hline $\begin{array}{l}\text { Delta River Over- } \\
\text { look C5 }\end{array}$ & $2285 \pm 145$ & Gx-6750 & $\mathrm{c}$ & stratigraphic & $2724-1952$ & $\begin{array}{l}\text { Bacon and } \\
\text { Holmes } 1980\end{array}$ \\
\hline $\begin{array}{l}\text { Broken Mammoth } \\
\text { CZ1A }\end{array}$ & $2280 \pm 40$ & unreported & $\mathrm{c}$ & hearth & $2352-2157$ & Holmes 2001 \\
\hline XBD-337 & $2180 \pm 40$ & Beta-2324 & $\mathrm{c}$ & stratigraphic & $2327-2063$ & Potter et al. 2007b \\
\hline Fish Creek concA11 & $2115 \pm 140$ & $G x-4108$ & $\mathrm{c}$ & Feature 1 & 2434-1719 & Cook et al. 1977 \\
\hline \multirow[t]{2}{*}{ Tok Terrace C2 } & $1650 \pm 60$ & Beta-40603 & $\mathrm{c}$ & stratigraphic & $1696-1409$ & $\begin{array}{l}\text { Sheppard et al. } \\
1991\end{array}$ \\
\hline & $1980 \pm 70$ & Beta-40712 & $\mathrm{c}$ & stratigraphic & $2121-1740$ & \\
\hline
\end{tabular}


Table A1 Radiocarbon-dated component date list (see Methods section for details). (Continued)

\begin{tabular}{|c|c|c|c|c|c|c|}
\hline Component $^{\mathrm{a}}$ & $\begin{array}{l}{ }^{14} \mathrm{C} \text { assay } \\
\text { (BP) }\end{array}$ & Lab \# & Material $^{\mathrm{b}}$ & Context $t^{c}$ & $\begin{array}{l}\text { Calib. yr BP } \\
\text { (2- } \sigma \text { range })\end{array}$ & Reference \\
\hline \multirow[b]{5}{*}{ average } & $2110 \pm 170$ & Beta-40721 & $\mathrm{c}$ & stratigraphic & $2684-1631$ & \\
\hline & $2630 \pm 90$ & Beta-40716 & $\mathrm{c}$ & stratigraphic & $2951-2369$ & \\
\hline & $2690 \pm 90$ & Beta- 42600 & $\mathrm{c}$ & stratigraphic & $3062-2497$ & \\
\hline & $2820 \pm 180$ & Beta- 40720 & $\mathrm{c}$ & stratigraphic & $3398-2487$ & \\
\hline & $2114 \pm 35$ & & & & 2296-1993 & \\
\hline TLM-217 C2 & $2070 \pm 60$ & Beta-9899 & $\mathrm{c}$ & stratigraphic & $2298-1886$ & Dixon et al. 1985 \\
\hline XBD-324 & $2070 \pm 50$ & Beta-219662 & $\mathrm{c}$ & stratigraphic & $2287-1899$ & Potter et al. 2007a \\
\hline Portage site $\mathrm{C} 1$ & $2009 \pm 225$ & not reported & $\mathrm{u}$ & unreported & $2675-1414$ & West 1972 \\
\hline XBD-296 & $2010 \pm 40$ & Beta-221334 & $\mathrm{c}$ & stratigraphic & $2103-1876$ & Potter et al. 2007a \\
\hline XBD-286 & $1860 \pm 50$ & Beta-220213 & $\mathrm{c}$ & stratigraphic & $1921-1634$ & Potter et al. 2007a \\
\hline $\begin{array}{l}\text { Little Panguingue } \\
\text { Creek C2 }\end{array}$ & $1825 \pm 68$ & AA-1699 & $\mathrm{c}$ & hearth & $1896-1569$ & $\begin{array}{l}\text { Hoffecker and } \\
\text { Powers } 1996\end{array}$ \\
\hline FAI-045 & $1820 \pm 70$ & DIC-1552 & $\mathrm{c}$ & $\begin{array}{l}\text { associated with } \\
\text { caribou bones }\end{array}$ & $1893-1567$ & Dixon et al. 1980 \\
\hline \multirow[t]{2}{*}{ Donnelly Ridge } & $1790 \pm 300$ & Beta-650 & $\mathrm{c}$ & stratigraphic & $2452-1062$ & West 1967,1981 \\
\hline & $1830 \pm 200$ & Beta-649 & $\mathrm{c}$ & stratigraphic & $2302-1338$ & \\
\hline average & $1818 \pm 166$ & & & & $2135-1377$ & \\
\hline Tuff Creek North C3 & $1800 \pm 55$ & DIC-2284 & so & stratigraphic & $1867-1571$ & Dixon et al. 1985 \\
\hline Hurricane Bluff C2 & $1750 \pm 40$ & Beta-123338 & $\mathrm{c}$ & stratigraphic & $1810-1553$ & $\begin{array}{l}\text { Potter et al. 2007c; } \\
\text { Higgs et al. } 1999\end{array}$ \\
\hline \multirow[t]{3}{*}{ TLM-216 } & $1880 \pm 50$ & Beta-9892 & $\mathrm{w}$ & stratigraphic & $1930-1705$ & Dixon et al. 1985 \\
\hline & $1670 \pm 50$ & Beta-9898 & w & stratigraphic & $1702-1417$ & \\
\hline & $1530 \pm 80$ & Beta-10125 & w & stratigraphic & $1596-1293$ & \\
\hline average & $1735 \pm 32$ & & & & $1714-1557$ & \\
\hline $\begin{array}{l}\text { Lake Minchumina } \\
\text { C2 (Levels } 2 \text { and } 3 \text {, } \\
\text { Cranberry phase) }\end{array}$ & $1610 \pm 150$ & Gx-4233 & $\mathrm{c}$ & stratigraphic & $1870-1273$ & Holmes 1986 \\
\hline $\begin{array}{l}\text { Watana Depression } \\
\text { site }\end{array}$ & $1580 \pm 110$ & Beta-7846 & & depression & $1715-1291$ & Dixon et al. 1985 \\
\hline \multirow[t]{5}{*}{ Swan Point CZ1A } & $1220 \pm 70$ & WSU-4523 & $\mathrm{c}$ & stratigraphic & $1285-982$ & Holmes et al. 1996 \\
\hline & $1570 \pm 70$ & WSU-4524 & $\mathrm{c}$ & stratigraphic & $1607-1316$ & \\
\hline & $1670 \pm 60$ & WSU-4522 & $\mathrm{c}$ & stratigraphic & $1706-1415$ & \\
\hline & $1750 \pm 80$ & WSU-4521 & $\mathrm{c}$ & stratigraphic & $1872-1423$ & \\
\hline & $1552 \pm 34$ & & & & $1526-1369$ & \\
\hline $\begin{array}{l}\text { Brown Scraper } \\
\text { Kame site }\end{array}$ & $1420 \pm 70$ & Beta-5653 & $\mathrm{c}$ & $\begin{array}{l}\text { associated with } \\
\text { calcined bone }\end{array}$ & $1515-1181$ & Dixon et al. 1985 \\
\hline Mead CZ1 & $1420 \pm 60$ & WSU-4348 & $\mathrm{c}$ & stratigraphic & $1507-1184$ & Dilley 1998 \\
\hline Red Scraper site C2 & $1380 \pm 155$ & DIC-2246 & $\mathrm{c}$ & stratigraphic & $1603-961$ & Dixon et al. 1985 \\
\hline \multirow[t]{2}{*}{ Borrow $\mathrm{C}$ site $\mathrm{C} 3$} & $1260 \pm 80$ & Beta-7845 & $\mathrm{c}$ & Feature 1 & $1305-983$ & Dixon et al. 1985 \\
\hline & $1400 \pm 55$ & DIC-2245 & $\mathrm{c}$ & stratigraphic & $1405-1184$ & \\
\hline average & $1355 \pm 45$ & & & & $1345-1179$ & \\
\hline \multirow[t]{2}{*}{ Healy Lake Garden } & $1260 \pm 90$ & GaK-1885 & $\mathrm{c}$ & hearth? & $1312-975$ & Cook 1969 \\
\hline & $1270 \pm 80$ & GaK-1884 & $\mathrm{c}$ & hearth? & $1311-985$ & \\
\hline average & $1266 \pm 60$ & & & & $1294-1063$ & \\
\hline \multirow[t]{2}{*}{ East Cove site } & $1360 \pm 120$ & Gx-5129 & $\mathrm{c}$ & house floor? & $1522-1002$ & Holmes 1986 \\
\hline & $1140 \pm 135$ & Gx-5997 & $\mathrm{c}$ & hearth & $1300-788$ & \\
\hline average & $1262 \pm 90$ & & & & $1314-975$ & \\
\hline Mount Hayes 130 & $1220 \pm 190$ & $\mathrm{I}-4232$ & $\mathrm{c}$ & $\begin{array}{l}\text { possible asso- } \\
\text { ciation with } \\
\text { housepit }\end{array}$ & $1515-742$ & West 1972 \\
\hline XBD-290 & $1170 \pm 40$ & Beta-219655 & $\mathrm{c}$ & stratigraphic & $1223-975$ & Potter et al. 2007a \\
\hline Kosina Creek B & $1160 \pm 100$ & DIC-1878 & $\mathrm{c}$ & hearth & $1290-918$ & Dixon et al. 1985 \\
\hline $\begin{array}{l}\text { Lake Minchumina } \\
\text { C3 (Level 1, Rasp- } \\
\text { berry phase) }\end{array}$ & $1140 \pm 120$ & Gx-2828 & $\mathrm{b}$ & from hearth & $1292-797$ & Holmes 1986 \\
\hline $\begin{array}{l}\text { Flood's Cabins } \\
\text { Cache Pits }\end{array}$ & $1050 \pm 60$ & WSU-2584 & $\mathrm{c}$ & $\begin{array}{l}\text { from storage } \\
\text { pit }\end{array}$ & $1118-795$ & Holmes 1986 \\
\hline
\end{tabular}


Table A1 Radiocarbon-dated component date list (see Methods section for details). (Continued)

\begin{tabular}{|c|c|c|c|c|c|c|}
\hline Component $^{\mathrm{a}}$ & $\begin{array}{l}{ }^{14} \mathrm{C} \text { assay } \\
\text { (BP) }\end{array}$ & Lab \# & Material $^{\mathrm{b}}$ & Context $\mathrm{t}^{\mathrm{c}}$ & $\begin{array}{l}\text { Calib. yr BP } \\
\text { (2- } \sigma \text { range })\end{array}$ & Reference \\
\hline \multirow[t]{3}{*}{ Chugwater C3 } & $870 \pm 50$ & Beta-7565 & $\mathrm{c}$ & hearth? & $910-693$ & $\begin{array}{l}\text { Maitland 1986; } \\
\text { Lively } 1996\end{array}$ \\
\hline & $950 \pm 105$ & Beta-9248 & $\mathrm{c}$ & hearth? & $1059-680$ & \\
\hline & $1120 \pm 90$ & Beta-7566 & $\mathrm{c}$ & hearth & $1269-803$ & \\
\hline average & $932 \pm 40$ & & & & $928-744$ & \\
\hline \multirow[t]{2}{*}{ Flat Knoll C3 } & $840 \pm 60$ & Beta-7692 & $\mathrm{c}$ & stratigraphic & $908-674$ & Dixon et al. 1985 \\
\hline & $1060 \pm 70$ & Beta-7693 & $\mathrm{c}$ & stratigraphic & $1170-796$ & \\
\hline average & $933 \pm 46$ & & & & $929-743$ & \\
\hline $\begin{array}{l}\text { Healy Lake Village } \\
\text { Level } 1\end{array}$ & $900 \pm 90$ & GaK-1886 & $\mathrm{c}$ & hearth & $962-675$ & Cook 1996 \\
\hline $\begin{array}{l}\text { Nenana River Dune } \\
\text { site }\end{array}$ & $800 \pm 50$ & Beta-196497 & $\mathrm{c}$ & from cache pit & $896-663$ & Potter 2004b \\
\hline Little Bones Ridge & $740 \pm 70$ & DIC-2253 & $\mathrm{c}$ & $\begin{array}{l}\text { structural tim- } \\
\text { ber }\end{array}$ & $793-552$ & Dixon et al. 1985 \\
\hline \multirow[t]{6}{*}{ Ringling site } & $460 \pm 100$ & Gx-4391 & $\mathrm{c}$ & $\begin{array}{l}\text { from storage } \\
\text { pit } 770302\end{array}$ & $652-305$ & Workman 1976 \\
\hline & $695 \pm 115$ & Gx-4300 & $\mathrm{c}$ & $\begin{array}{l}\text { from storage } \\
\text { pit } 29\end{array}$ & $904-509$ & \\
\hline & $760 \pm 125$ & Gx-4299 & $\mathrm{c}$ & $\begin{array}{l}\text { from storage } \\
\text { pit } 50\end{array}$ & $924-538$ & \\
\hline & $765 \pm 125$ & Gx-4298 & $\mathrm{c}$ & $\begin{array}{l}\text { from storage } \\
\text { pit } 29\end{array}$ & $925-540$ & \\
\hline & $720 \pm 60$ & WSU-4922 & $\mathrm{c}$ & $\begin{array}{l}\text { timbers from } \\
\text { housepit 95-36 }\end{array}$ & $762-553$ & Hanson 1999 \\
\hline & $780 \pm 70$ & WSU-4923 & $\mathrm{c}$ & hearth & $905-563$ & Hanson 1999 \\
\hline average & $707 \pm 36$ & & & & $721-562$ & \\
\hline Birches site & $640 \pm 95$ & $\mathrm{I}-2617$ & $\mathrm{c}$ & from house 5 & $737-504$ & West 1978 \\
\hline $\begin{array}{l}\text { Tok Terrace Cluster } \\
\text { G, upper component }\end{array}$ & $640 \pm 70$ & Beta-34233 & $\mathrm{c}$ & $\begin{array}{l}\text { from burned } \\
\text { rock layer in } \\
\text { steambath }\end{array}$ & $451-0$ & Gerlach et al. 1989 \\
\hline \multirow[t]{2}{*}{ GUL-076 } & $550 \pm 135$ & Gx-3855 & $\mathrm{c}$ & hearth & $738-300$ & Clark 1974 \\
\hline & $690 \pm 135$ & Gx-3859 & $\mathrm{c}$ & $\begin{array}{l}\text { planking from } \\
\text { housepit }\end{array}$ & $921-498$ & \\
\hline average & $620 \pm 95$ & & & & $730-502$ & \\
\hline \multirow[t]{4}{*}{ Tok Terrace C3 } & $920 \pm 90$ & Beta-40722 & $\mathrm{c}$ & stratigraphic & $1042-677$ & $\begin{array}{l}\text { Sheppard et al. } \\
1991\end{array}$ \\
\hline & $570 \pm 80$ & Beta-40713 & $\mathrm{c}$ & stratigraphic & $677-495$ & \\
\hline & $450 \pm 90$ & Beta-40718 & $\mathrm{c}$ & stratigraphic & $643-305$ & \\
\hline & $640 \pm 50$ & & & & $671-545$ & \\
\hline \multirow{2}{*}{ Dixthada $\mathrm{C} 2$} & $770 \pm 40$ & P-1832 & $\mathrm{c}$ & base of midden & $764-661$ & Shinkwin 1979 \\
\hline & $390 \pm 50$ & P-1833 & $\mathrm{c}$ & base of midden & $515-315$ & \\
\hline average & $622 \pm 31$ & & & & $659-551$ & \\
\hline \multirow[t]{2}{*}{ Batzulnetas Village } & $410 \pm 80$ & Beta-56552 & $\mathrm{c}$ & unreported & $619-296$ & AHRS (n.d.) \\
\hline & $570 \pm 100$ & Beta-56551 & $\mathrm{c}$ & unreported & $722-322$ & \\
\hline average & $472 \pm 62$ & & & & $639-319$ & \\
\hline VAL-206 & $460 \pm 70$ & Beta-6692 & $\mathrm{c}$ & hearth & $635-316$ & Reger 1985 \\
\hline TLM-253 & $430 \pm 130$ & Beta-10796 & $\mathrm{c}$ & $\begin{array}{l}\text { associated with } \\
\text { FCR, calcined } \\
\text { bone }\end{array}$ & $668-0$ & Dixon et al. 1985 \\
\hline TLM-250 & $370 \pm 80$ & Beta-10798 & $\mathrm{c}$ & hearth & $535-156$ & Dixon et al. 1985 \\
\hline \multirow{2}{*}{$\begin{array}{l}\text { Nenana River Gorge } \\
\text { site } C 1\end{array}$} & $460 \pm 115$ & I-9882 & $\mathrm{c}$ & hearth & $666-288$ & Plaskett 1977 \\
\hline & $260 \pm 75$ & I-9883 & $\mathrm{c}$ & hearth & $498-0$ & \\
\hline average & $320 \pm 63$ & & & & $505-154$ & \\
\hline Tsusena Creek C1 & $300 \pm 70$ & DIC-2252 & $\mathrm{c}$ & hearth & $506-0$ & Dixon et al. 1985 \\
\hline O'Brian Creek & $280 \pm 60$ & Beta-56665 & $\mathrm{c}$ & unreported & $496-0$ & Reger et al. 1975 \\
\hline
\end{tabular}


Table A1 Radiocarbon-dated component date list (see Methods section for details). (Continued)

\begin{tabular}{|c|c|c|c|c|c|c|}
\hline Component $^{\mathrm{a}}$ & $\begin{array}{l}{ }^{14} \mathrm{C} \text { assay } \\
\text { (BP) }\end{array}$ & Lab \# & Material $^{\mathrm{b}}$ & Context ${ }^{c}$ & $\begin{array}{l}\text { Calib. yr BP } \\
(2-\sigma \text { range })\end{array}$ & Reference \\
\hline Permafrost Creek & $280 \pm 110$ & DIC-1905 & $\mathrm{c}$ & hearth & $511-0$ & Dixon et al. 1985 \\
\hline average & $\begin{array}{l}280 \pm 245 \\
280 \pm 100\end{array}$ & DIC-1904 & $\mathrm{c}$ & hearth & $\begin{array}{l}650-0 \\
510-0\end{array}$ & \\
\hline Bendildenden & $260 \pm 70$ & Beta- 6828 & $\mathrm{c}$ & hearth & $497-0$ & Reger 1985 \\
\hline $\begin{array}{l}\text { Butte Lake C4 } \\
\qquad \text { average }\end{array}$ & $\begin{array}{l}110 \pm 60 \\
180 \pm 60 \\
145 \pm 42\end{array}$ & $\begin{array}{l}\text { DIC-3068 } \\
\text { DIC-3069 }\end{array}$ & $\begin{array}{l}\mathrm{c} \\
\mathrm{c}\end{array}$ & $\begin{array}{l}\text { Feature } 2 \\
\text { Feature } 6\end{array}$ & $\begin{array}{l}281-0 \\
307-0 \\
283-0\end{array}$ & Betts 1987 \\
\hline
\end{tabular}

a Site prefixes relate to USGS 250,000 scale quadrangles (ANC - Anchorage, FAI - Fairbanks, HEA - Healy, GUL - Gulkana, NAB - Nabesna, TLM - Talkeetna Mountains, VAL - Valdez, XBD - Big Delta, XMH - Mount Hayes). Components are labeled as $\mathrm{C \#}$ - component, $\mathrm{CH}$ - cultural horizon, $\mathrm{CZ \#} \mathrm{-} \mathrm{cultural} \mathrm{zone.}$

${ }^{\mathrm{b}}$ Material: $\mathrm{c}$ - charcoal; iv - ivory; o - organic residue; so - soil organics; $\mathrm{u}$ - unreported.

${ }^{\mathrm{c}}$ Abbreviations: ULD - upper limiting date; LLD - lower limiting date; FCR - fire-cracked rock. 